\title{
Homogenization and Assessment of Observed Near-Surface Wind Speed Trends over Spain and Portugal, 1961-2011*
}

\author{
Cesar Azorin-Molina, ${ }^{+}$Sergio M. Vicente-Serrano, ${ }^{+}$Tim R. McVicar, ${ }^{\#}$ Sonia Jerez, ${ }^{@}$

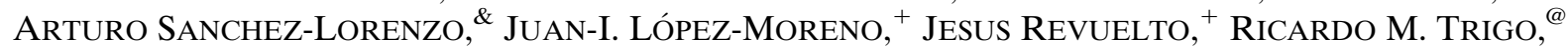 \\ JOAN A. LOPEZ-BUSTINS,** AND FÁTIMA ESPÍRITO-SANTO ${ }^{++}$ \\ ${ }^{+}$Instituto Pirenaico de Ecología, Departamento de Procesos Geoambientales y Cambio Global, \\ Consejo Superior de Investigaciones Científicas, Zaragoza, Spain \\ ${ }^{*}$ CSIRO Land and Water, Canberra, Australian Capital Territory, Australia \\ ${ }^{\circledR}$ Instituto Dom Luiz, Universidade de Lisboa, Lisboa, Portugal \\ \& Group of Environmental Physics, Department of Physics, University of Girona, Girona, Spain \\ ** Grup de Climatologia, Facultat de Geografia i Història, Universitat de Barcelona, Barcelona, Spain \\ ${ }^{++}$Instituto Português do Mar e da Atmosfera, Lisboa, Portugal
}

(Manuscript received 24 October 2013, in final form 27 January 2014)

\begin{abstract}
Near-surface wind speed trends recorded at 67 land-based stations across Spain and Portugal for 1961-2011, also focusing on the 1979-2008 subperiod, were analyzed. Wind speed series were subjected to quality control, reconstruction, and homogenization using a novel procedure that incorporated the fifth-generation Pennsylvania State University-National Center for Atmospheric Research Mesoscale Model (MM5)-simulated series as reference. The resultant series show a slight downward trend for both 1961-2011 $\left(-0.016 \mathrm{~m} \mathrm{~s}^{-1} \mathrm{decade}^{-1}\right)$ and 1979-2008 $\left(-0.010 \mathrm{~m} \mathrm{~s}^{-1}\right.$ decade $\left.^{-1}\right)$. However, differences between seasons with declining values in winter and spring, and increasing trends in summer and autumn, were observed. Even though wind stilling affected $77.8 \%$ of the stations in winter and $66.7 \%$ in spring, only roughly $40 \%$ of the declining trends were statistically significant at the $p<0.10$ level. On the contrary, increasing trends appeared in $51.9 \%$ of the stations in summer and $57.4 \%$ in autumn, with also around $40 \%$ of the positive trends statistically significant at the $p<0.10$ level. In this article, the authors also investigated (i) the possible impact of three atmospheric indices on the observed trends and (ii) the role played by the urbanization growth in the observed decline. An accurate homogenization and assessment of the long-term trends of wind speed is crucial for many fields such as wind energy (e.g., power generation) and agriculture-hydrology (e.g., evaporative demand).
\end{abstract}

\section{Introduction}

Near-surface wind speed links the land surface with the lower atmosphere and partially governs the transfer of energy, water, and momentum between the two. While most climate change and variability research has traditionally focused on air temperature and precipitation,

\footnotetext{
* Supplemental information related to this paper is available at the Journals Online website: http://dx.doi.org/10.1175/JCLI-D-1300652.s1.

Corresponding author address: Cesar Azorin-Molina, Instituto Pirenaico de Ecología, Departamento de Procesos Geoambientales y Cambio Global, Consejo Superior de Investigaciones Científicas, Avda. Montañana 1005, 50059-Zaragoza, Spain.

E-mail: cazorin@ipe.csic.es
}

only over the last $20 \mathrm{yr}$ have near-surface wind speed characteristics been researched (e.g., Cardone and Greenwood 1990; Coelingh et al. 1996; Klink 1999). An unexpected outcome of this has been the widespread decline in measured near-surface wind speed (termed "global stilling"; Roderick et al. 2007). This has been reported in the United States (Klink 1999; Pryor et al. 2009), China (Xu et al. 2006; Guo et al. 2011), Australia (McVicar et al. 2008), the Netherlands (Smits et al. 2005), Czech Republic (Brázdil et al. 2009), and Iran (Rahimzadeh et al. 2011), among many other locations (McVicar et al. 2012a, and the references therein). Positive wind speed trends have also been found for specific regions that are usually coastal and/or high latitudes (Pinard 2007), even though McVicar et al. (2012a) confirmed that terrestrial stilling is a widespread phenomenon across much of the globe. The cause of the 
terrestrial wind speed stilling is currently unresolved and has been hypothetically attributed to several factors (e.g., McVicar et al. 2012a, and the references therein), mainly related to an increasing surface roughness (i.e., forest growth, land use changes, and urbanization; see Vautard et al. 2010; Wever 2012) and a slowdown in large-scale atmospheric circulation (Lu et al. 2007). In contrast, Wentz et al. (2007) concluded that wind speed trends have increased over ocean surfaces; this suggests a local cause as opposed to global and/or latitudinally dependent causes (McVicar et al. 2012a,b).

Knowledge about future near-surface wind speed regimes has direct implications in many fields, but especially in wind energy by altering the long-term power generation capacity (Otero et al. 2012) and in agriculture and hydrology because of the importance of wind trends governing declining rates of atmospheric evaporative demand (as measured by pan evaporation; McVicar et al. 2012a,b). Therefore, it is of great scientific, socioeconomic, and environmental interest to investigate for the first time observed wind speed trends over other areas such as the Iberian Peninsula and the Balearic Islands (henceforth denoted by IP, covering both geographic regions), covering Spain and Portugal. The IP has diverse wind regimes, which are mainly affected by geophysical variables such as their complex terrain (i.e., high surface roughness) with an average elevation of $650 \mathrm{~m}$ MSL ( $18.4 \%$ is above $1000 \mathrm{~m} \mathrm{MSL}$ and a standard deviation of $426.2 \mathrm{~m}$ ) and influence from the surrounding Atlantic Ocean and the Mediterranean Sea. Furthermore, because of its location in the temperate midlatitudes (between $36^{\circ}$ and $44^{\circ} \mathrm{N}$ ), the region is influenced by both the polar and the subtropical front jet streams (Barry and Chorley 2003). In general, westerly and northwesterly large-scale synoptic flows prevail during the cold semester (November through April) (Azorin-Molina and Martin-Vide 2007), whereas during the warm semester (May through October) the Iberian thermal low and its pressure gradients (Hoinka and de Castro 2003) cause low-level winds (i.e., sea breezes; Azorin-Molina et al. 2011) to blow from the coastal zones inland.

Homogenizing wind speed series and assessing the spatiotemporal trends of near-surface wind speed across the IP is important because (i) there are few studies in the scientific literature dealing with the homogenization of wind speed data (Dadaser-Celik and Cengiz 2014); (ii) few studies for few stations (i.e., maximum of 14 stations) and short periods of time (i.e., maximum length of $39 \mathrm{yr}$ ) have assessed wind speed trends over this region (see study numbers $43,44,45,48$, and 50 in Table 2 of McVicar et al. 2012a); and (iii) these studies have not clearly shown a consistent wind speed trend, with increasing and decreasing wind speed trends reported in the vicinity of the Mediterranean Sea/Middle East as a result of complex mesoscale atmospheric circulation developed in this area (Evans et al. 2004). Therefore, a comprehensive study is needed for this midlatitude Mediterranean area that represents an important "hot spot" of climate change (Bernstein et al. 2007).

Our overall objective is to analyze the observed terrestrial wind speed trends in the IP to assess if atmospheric stilling is observed over this midlatitude region. Primary aims are (i) to obtain high-quality near-surface wind speed series by means of a detailed compilation, homogenization, and trend analysis of data (sections 2, 3 , and 4) and (ii) to assess the spatiotemporal variability and long-term trends of near-surface wind speed in Spain and Portugal for $51 \mathrm{yr}$ from 1961 to 2011 (section 5). Secondary aims are to investigate possible attribution of observed wind speed trends to (iii) changes in large-scale atmospheric circulation and (iv) urbanization-induced increases in roughness (both reported in section 6). Last, a summary and discussion is drawn (section 7).

\section{Datasets}

\section{a. Observed wind speed data}

McVicar et al. (2012a) strongly encouraged future researchers to provide information on the anemometer type and calibration for studies dealing with long-term trends of wind speed. Wind speed data supplied by the Spanish Meteorological Agency (AEMET) and the Portuguese Sea and Atmosphere Institute (IPMA) were measured by different types of anemographs and anemometers (supplementary Fig. S1). For Spain, the anemograph universal 82a with mechanical and pneumatic transmission manufactured by Dr. Alfred Müller (Meteorologische Instrumente KG, R. Fuess; technical specifications regarding the anemograph universal 82a can be found online at http://www.rfuess-mueller.de/ $\mathrm{html} /$ anemograph_universal_.html) was used in all "first-order" weather stations for recording wind direction, wind run, and wind speed gusts until around the mid-1980s. Since then, AEMET installed an automatic weather station (AWS) with the anemograph universal 82a systematically replaced by the 3-cup Sociedad Española de Aplicaciones Cibernéticas SA (SEAC) anemometer SV5, which has been in continual operation since. At airport weather stations, the anemometer from Munro Meteorological Instruments (Munro Mark II) was used as aviation operations required reporting meteorological terminal aviation routine weather report (METAR weather reports). For Portugal, several types of anemometers have been in use, the most common is the Munro Mark II followed by the anemograph universal 82a, the anemometer SIAP VT 127, the anemometers 


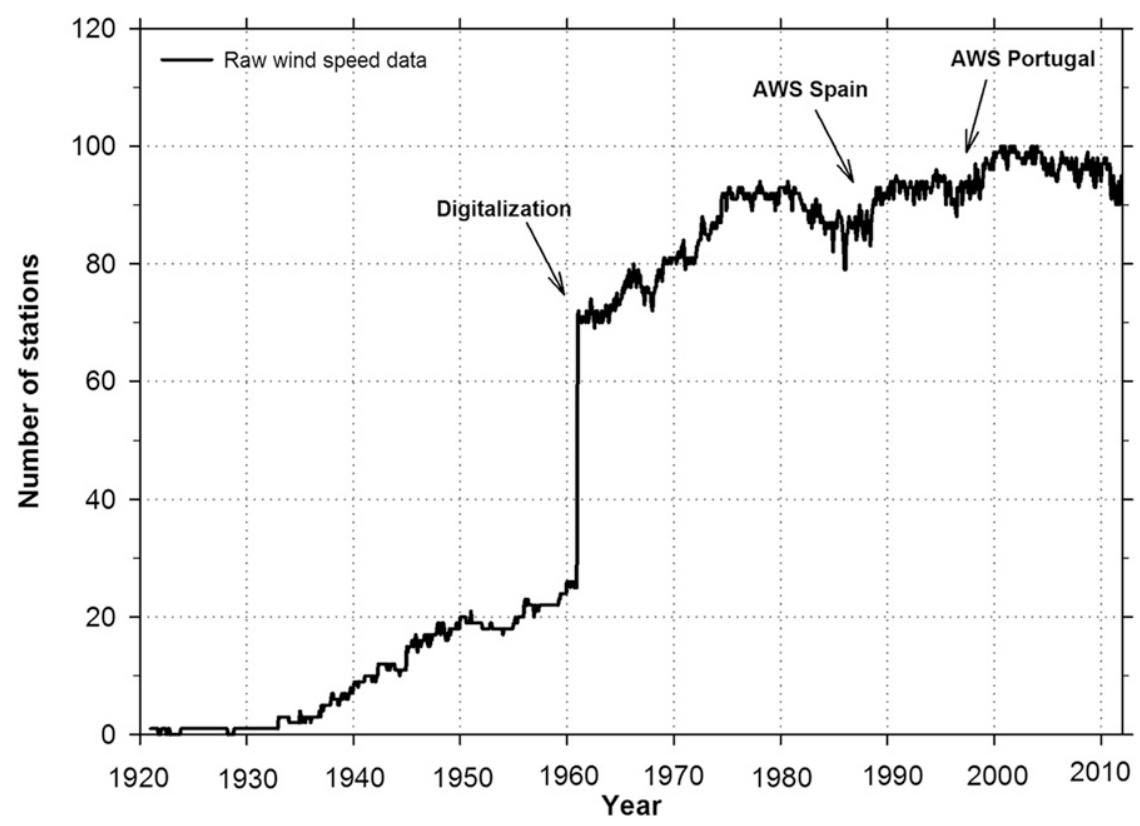

FIG. 1. Time series of the number of stations recording wind speed data in Spain and Portugal for 1921-2011.

Casella W 1208/2, W1404, and W1762, and the anemometer Woelfe Lambrecht 1482 and 1425. Between 1997 and 2001, the IPMA began mounting new automatic sensors that replaced analog weather instruments.

Regardless of the different type of anemograph or anemometer, the original monthly-mean near-surface wind speed series (in $\mathrm{m} \mathrm{s}^{-1}$ ) supplied by the AEMET were obtained from daily mean wind speed data averaged from standard 10-min mean observations at 0000 , 0700, 1300, and 1800 UTC (i.e., a difference of $1 \mathrm{~h}$ for two of the World Meteorological Organization's standard observing times of 0600 and 1200 UTC), whereas monthly-mean near-surface wind speed series from the IPMA were computed from daily wind run data (i.e., the total distance of the traveled wind over $24 \mathrm{~h}$ ) from 0900 till 0900 UTC and from hourly mean wind speed data for AWS. The original wind speed data supplied by the IPMA in kilometers per hour were converted to meters per second. For mean hourly and daily wind speed measurements, we computed corresponding monthly-mean values only for days with three or more observations and for those months having at least 26 days of observations, respectively, and if not, the whole day or month was excluded and set as missing.

The original (i.e., raw) wind speed database comprises 129 series (113 for Spain and 16 for Portugal) and covers the entire IP, the only exception being the Spanish station of Melilla (number 64 in Fig. 2b) located in North Africa. Figure 1 displays the temporal evolution of nearsurface wind speed data availability from January 1921
(1 station) to December 2011 (95 stations). The most noteworthy feature is the abrupt increase in stations between December 1960 (25 stations) and January 1961 (71 stations) due to the widespread digitalization of climate series carried out at the weather services. After this date, the number of stations progressively increased until the 1980s, followed by a decrease in the mid-1980s and a new increase from this date onward in Spain and from the mid-1990s onward in Portugal due to the installation of the first AWS. The number of stations oscillated between 90 and 100 during last decade. From the original wind speed database, we selected those series that corresponded to the (i) longest series with few missing data (no more than 60 months, i.e., $5 \mathrm{yr}$ ) covering the 51 yr (1961-2011); (ii) series with few missing data (no more than 36 months, i.e., $3 \mathrm{yr}$ ) covering the 30-yr (1979-2008) subperiod (the same period used in Vautard et al. 2010; see section 4); and (iii) series with less than $30 \mathrm{yr}$ of data due to relocation (see the section $3 b)$. Taking into account these considerations, 76 wind speed series (68 in Spain and 8 in Portugal) were subject to the homogenization procedure described in detail in section 3 .

\section{b. Modeled wind speed data}

A novel aspect of this study is the application of a regional climate model, the Pennsylvania State UniversityNational Center for Atmospheric Research Mesoscale Model (MM5) (Grell et al. 1994), for simulating the wind speed field. The ability of MM5 to reproduce long-term 


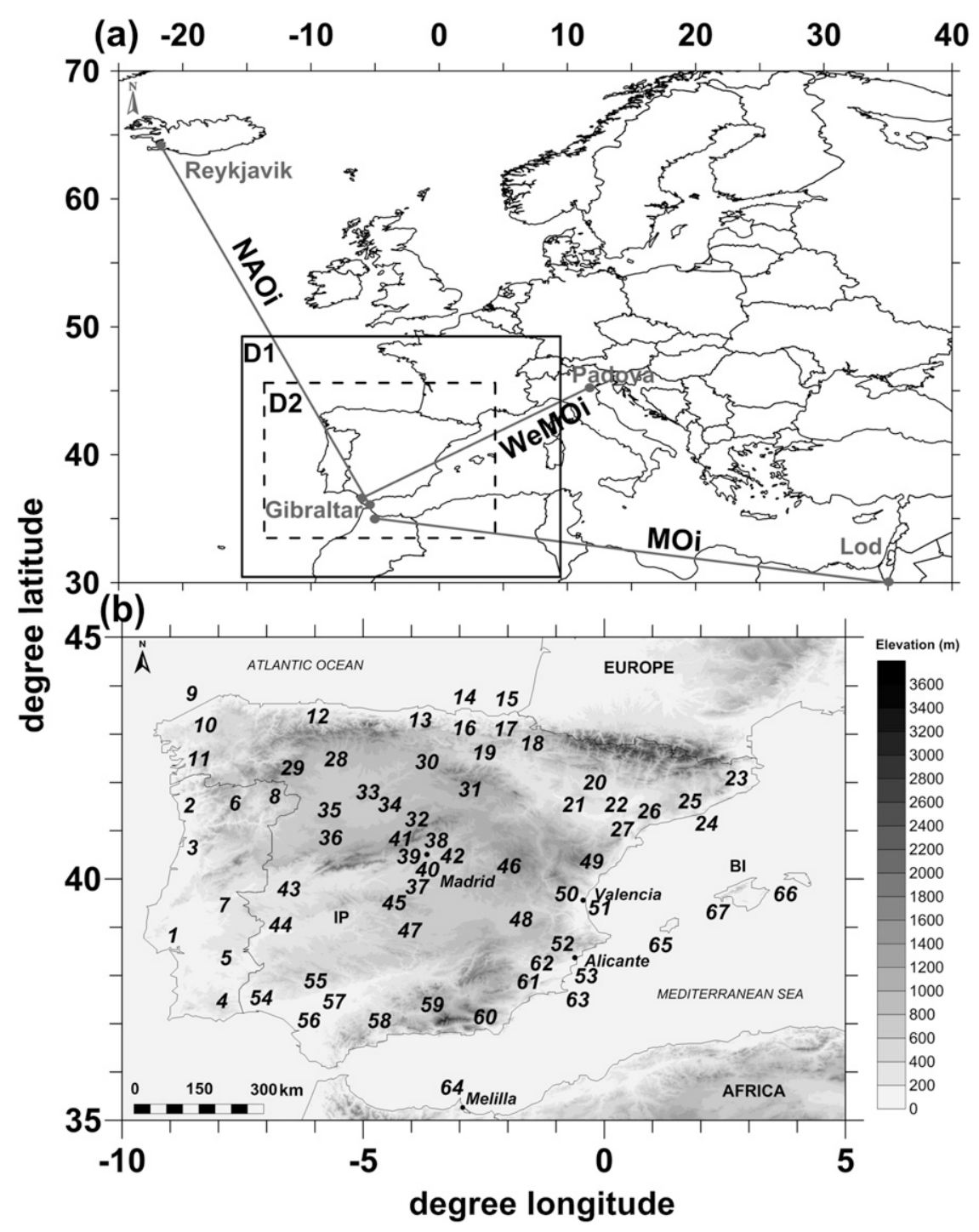

FIG. 2. Location of the atmospheric circulation large-scale circulation modes and stations used here. (a) MM5 spatial model configuration showing the coarse domain with a horizontal grid length of $30 \mathrm{~km}$ (D1; black solid line) and the inner domain with a horizontal grid length of $10 \mathrm{~km}$ (D2; black dashed line). The map also shows transects of the atmospheric circulation indices (NAOI, MOI, and WEMOI; in dark gray solid lines) used here. (b) Terrain map of the IP showing the complex topography of the study area and location (for numbers see supplementary Table S1) of the wind speed network.

wind speed trends, mesoscale circulations, and different wind regimes has been widely demonstrated (e.g., Pryor et al. 2009; Kanamitsu et al. 2002), including simulation over the IP (Lorente-Plazas et al. 2012; Jerez et al. 2013b). Hence, we used the simulated wind speed as "reference series" for adjusting all significant mean shifts in the 76 original series of our observational network. The spatial configuration used in the MM5 simulation consisted of two-way nested domains with horizontal grid resolutions of $30 \mathrm{~km}$ (outer domain; D1) and $10 \mathrm{~km}$ (inner domain; D2), the last covering the entire IP
(Fig. 2a), and a dense vertical layer structure involving 27 inhomogeneous levels (more closely spaced near the surface) with the top layer at $100 \mathrm{hPa}$. It is worth stressing that the unusually high, within the context of climate simulations, horizontal grid resolution (i.e., $10 \mathrm{~km}$ ) allows the impact of local features such as complex terrain and land use on surface wind characteristics to be captured (Jiménez et al. 2006; Hughes et al. 2009). The comprehensive set of physical-based parameters used in the MM5 model to account for a variety of subgrid-scale processes are based on previous 
tests (Jerez et al. 2010, 2013a) and are detailed in Jerez et al. (2013b). The MM5 simulation spans 1961-2011. The 40-yr European Centre for Medium-Range Weather Forecasts (ECMWF) Re-Analysis (ERA-40; Uppala et al. 2005) supplied the initial and boundary conditions for the MM5 runs from 1961 to 2002; from 2003 onward, ECMWF analysis output were used. The simulation was performed by $1-y r$ continuous runs with 1 month of spinup at the beginning of each reinitialization. MM5 outputs were recorded at hourly intervals, from which we obtain the monthly means of the 10-m height (McVicar and Körner 2013) wind speed, one of the MM5 prognostic variables. The series for the specific location of each station were interpolated from the nearest grid cells, excluding those corresponding to water bodies.

\section{c. Atmospheric circulation indices}

Three atmospheric teleconnection indices, (i) the North Atlantic Oscillation index (NAOI), (ii) the Mediterranean oscillation index (MOI), and (iii) the western Mediterranean oscillation index (WEMOI), were selected to study the possible influence of large-scale atmospheric circulation on the observed wind speed variability. These three atmospheric indices drive much of the climate variability across the IP (e.g., Palutikof 2003; Martin-Vide and Lopez-Bustins 2006; VicenteSerrano and Trigo 2011; and the references therein). The NAOI, based on the difference of normalized sea level pressure between southwest IP (Gibraltar) and southwest Iceland (Reykjavik) as defined by Jones et al. (1997), was obtained from the Climatic Research Unit (available online at http://www.cru.uea.ac.uk/cru/data/ nao/; last accessed 1 October 2013) using station-derived pressure series. The MOI, based on the normalized sea level pressure difference between southwest IP (Gibraltar) and Lod (Israel) (Palutikof 2003), was computed as the normalized difference between the sea level pressure at $35^{\circ} \mathrm{N}, 5^{\circ} \mathrm{W}$ and that at $30^{\circ} \mathrm{N}, 35^{\circ} \mathrm{E}$, using daily sea level pressure grids from the Daily Northern Hemisphere Sea Level Pressure Grids dataset (available online at http://rda.ucar.edu/datasets/ds010.0/; last accessed 1 October 2013) (Trenberth and Paolino 1980). Finally, the WeMOI, based on the pressure dipole of normalized sea level pressure between southwest IP (San Fernando) and northeast Italy (Padova) as proposed by Martin-Vide and Lopez-Bustins (2006), was downloaded from the Group of Climatology of the University of Barcelona (available online at http://www. ub.edu/gc/English/wemo.htm; last accessed 1 October 2013). The location of the stations or grid points used to calculate the three atmospheric circulation indices are shown in Fig. 2a.

\section{Homogenization of wind speed series}

Long-term wind speed series are subject to inhomogeneities resulting from (i) station relocations, (ii) anemometer height changes, (iii) instrumentation malfunctions, (iv) instrumentation changes, (v) different sampling intervals, and (vi) observing environment changes (Pryor et al. 2009). Among these systematic errors, Wan et al. (2010) stated that station relocations and anemometer height changes are the main causes for discontinuities. For the IP, comprehensive station diaries describing all these changes are unavailable and impossible to recover. The only available metadata are station relocations and a few instrumentation changes, which are considered in the homogenization process described below. Because of the limited metadata, we assumed that wind speed measurements were acquired at the standard $10 \mathrm{~m}$, as recommended by WMO (2008), or at greater heights (i.e., between 10 and $30 \mathrm{~m}$ when the anemometers were mounted on the roofs of buildings to ensure an unobstructed exposure) and the following multistep approach was applied to create robust wind speed series: (i) quality control, (ii) reconstruction, and (iii) homogenization.

\section{a. Quality control}

The available wind speed series were recorded at firstorder meteorological stations operating $24 \mathrm{~h}$ a day and maintained by official weather service staff that ensured wind speed measurements to be accurately and periodically calibrated and handled with care. Additionally, many of these stations are located in airports, which are generally well-exposed sites and ensure less immediate proximal environment changes. The raw wind speed data first passed quality controls by the IPMA and the AEMET in order to remove incorrect/aberrant data and to check for data consistency, for both 10-min and hourly measurements. The raw wind speed data first passed quality controls by the IPMA and the AEMET in order to remove incorrect/aberrant data and to check for data consistency, for both 10-min and hourly measurements. We also applied a quality control check (Aguilar et al. 2003) to remove gross errors due to archiving, transcription, and digitalization (El Kenawy et al. 2013). This basically consisted of screening out suspicious wind speed values (outliers), that is, $\leq 0.1 \mathrm{~m} \mathrm{~s}^{-1}$ or $\geq 10.0 \mathrm{~m} \mathrm{~s}^{-1}$, because we verified that monthly means cannot exceed these thresholds in any of the studied locations.

\section{b. Reconstruction}

Reconstruction is crucial for estimating long-term climate changes as fragmented series may alter the magnitude and sign of climate trends (Vose et al. 1992). 
Long-term complete wind speed datasets (i.e., 19612011) were obtained by using all available data over the IP. Concatenation of wind speed series for stations that were relocated occurred (this was performed for 5 Spanish and 2 Portuguese stations; see the example of the Coimbra Aeródromo station in Fig. 4 and supplementary Table S1). Concatenation was also applied when traditional weather stations ceased to record data and were systematically replaced by AWS. We registered the dates when series were joined in order to check for inhomogeneities during the homogenization process.

\section{c. Homogenization}

Although wind speed homogenization is much more difficult than that for other variables, using a nonqualitycontrolled nor homogenized dataset is a noticeable source of uncertainty in the assessment of climate trends (Aguilar et al. 2003). To test the homogeneity of the selected 76 testable monthly wind speed series we applied the well-established relative Alexandersson's standard normal homogeneity test (SNHT; Alexandersson 1986) using the AnClim package (http://www.climahom.eu/ software-solution/anclim; last accessed 1 October 2013) developed by Stepanek (2004). The SNHT is probably the most widely used test for detecting inhomogeneities in climate series, being similar in quality than other approaches (Venema et al. 2012) and enabling the detection of small and multiple breaks in a series. Wan et al. (2010) also used another relative homogeneity test, the PMTred algorithm (under the RhtestV2 data homogenization package), to detect sudden breakpoints in the monthly-mean wind speed series and estimate the magnitude of the statistically detected shifts in order to adjust inhomogeneities. Moreover, Petrović et al. (2008) and Li et al. (2011) used the Multiple Analysis of Series for Homogenization (MASH) package as an objective technique to detect breakpoints and adjust the inhomogeneities in wind speed series.

Here we detail a novel approach to homogenize wind speed series by means of robust reference series based on monthly wind speed data simulated by MM5 instead of geostrophic winds (e.g., Wan et al. 2010) or nearest stations (Wang 2008), because in areas of complex topography surrounded by ocean/sea surfaces, wind is not solely driven by surface pressure gradients (i.e., it is also governed by Earth's surface friction force), and the spatial dependency among observatories can markedly degrade over short distances. Figure 3a illustrates this feature; that is, the average Pearson's correlation coefficient between each wind speed series and the series separated at different distances ranges between 0.3 and 0.4 for short distances $(\sim 25 \mathrm{~km})$ and decreased to between 0.1 and 0.2 for long distances $(\sim 900 \mathrm{~km})$. The average distance between each station and its five closest neighboring stations (from the set of 76 stations) is $100.5 \mathrm{~km}$. This precluded the generation of reference series from neighboring observations for which the average correlation is less than 0.4 . The relative frequency histogram shown in Fig. 3b confirms that the MM5 wind speed series showed better correlation when compared to the original series, displaying Pearson's correlation coefficients generally exceeding 0.6. Moreover, Fig. 3c shows the Pearson's correlation coefficients between the wind speed series measured at four locations (i.e., Lisboa, Zaragoza, Tortosa, and San Sebastian) and their corresponding MM5 reference series at each station and these four locations and their nearest stations placed at different distances, ranging from long distances $(\sim 135 \mathrm{~km}$ in Lisboa-Beja), medium distances $(\sim 70 \mathrm{~km}$ in Zaragoza-Huesca and $\sim 65 \mathrm{~km}$ in Tortosa-Reus), and short distances ( $\sim 15 \mathrm{~km}$ in San Sebastian-Hondarribia). Note that Pearson's correlation coefficients show a stronger positive relationship for the modeled MM5 series than for the observed nearest series for almost all months in each of these four paired locations. Therefore, we assumed that the site-specific MM5 reference wind speed series are better reference series than neighboring ones: that is, they are not affected by the aforementioned causes of discontinuities and reveal the same wind variability exhibited in the candidate stations.

SNHT was applied to all 76 candidate stations on a monthly basis using the MM5 series as the reference at each station. Inhomogeneities found within $5 \mathrm{yr}$ at the start and end of the wind speed series were rejected to avoid a low number of years affecting the detection of inhomogeneities given low stability of average values (Gokturk et al. 2008). Figure 4 displays the detection of a noticeable breakpoint in the monthly wind speed series of Coimbra (Portugal) by means of the SNHT test. This wind time series is a good example because metadata were available and subject to relocation (e.g., change in station elevation and observing environment) and anemometer height and anemometer-type changes. Specifically, the Coimbra Geofísico station (141 m MSL; 549 code) functioned between January 1961 and April 1996 and was then relocated to Coimbra Aeródromo (170 m MSL; 548 code) and has been in full operation since then. The anemometer height changed from 10.5 to $4.0 \mathrm{~m}$ above the ground, and the Lambrecht anemograph 1482 (Woelfe type) was replaced by the Casella anemometer W1208/2. All these artificial shifts were responsible for producing a statistically significant $(5 \%$ level) breakpoint for almost all months around 1993-99, as revealed by the $T$ value. These significant mean shifts shown in Fig. 4 were higher from October to March, when stronger winds dominated. Therefore, we adjusted the monthly wind speed series to the most ancient 
(a)

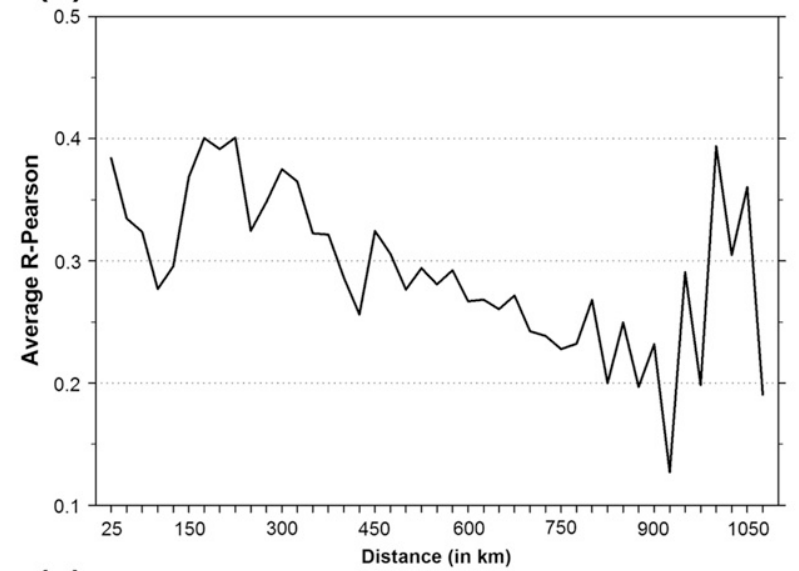

(b)

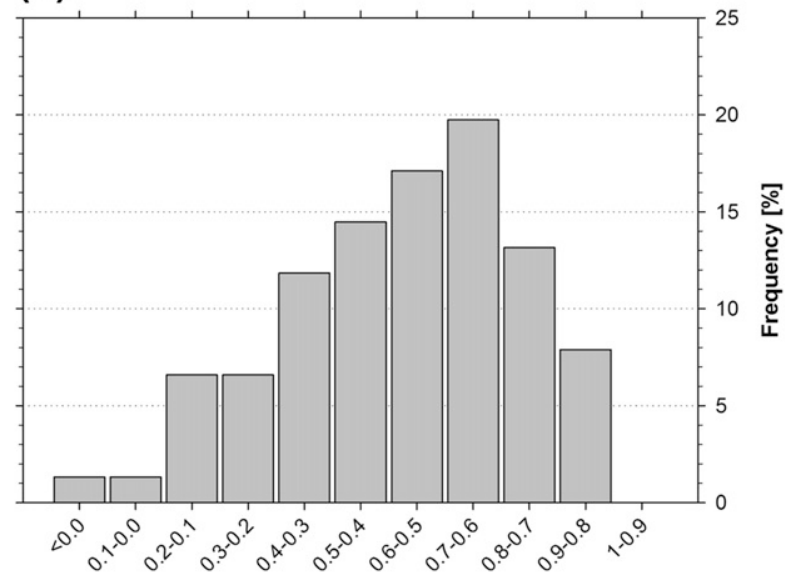

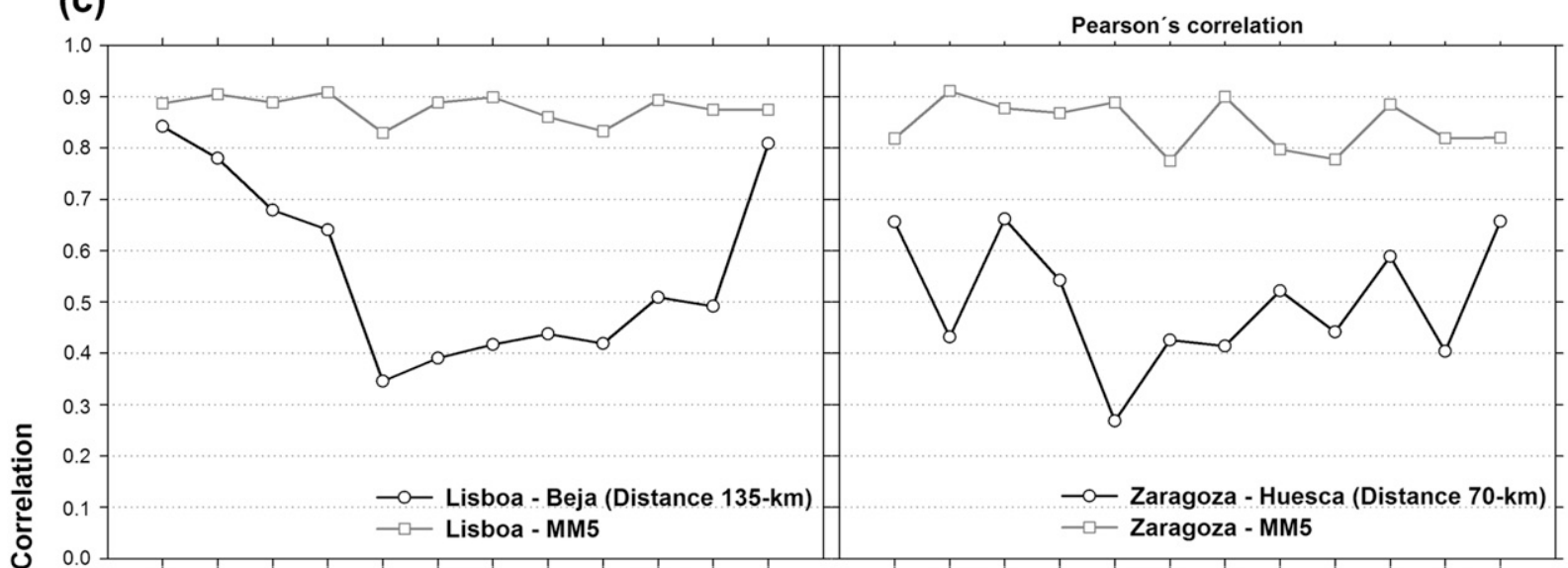

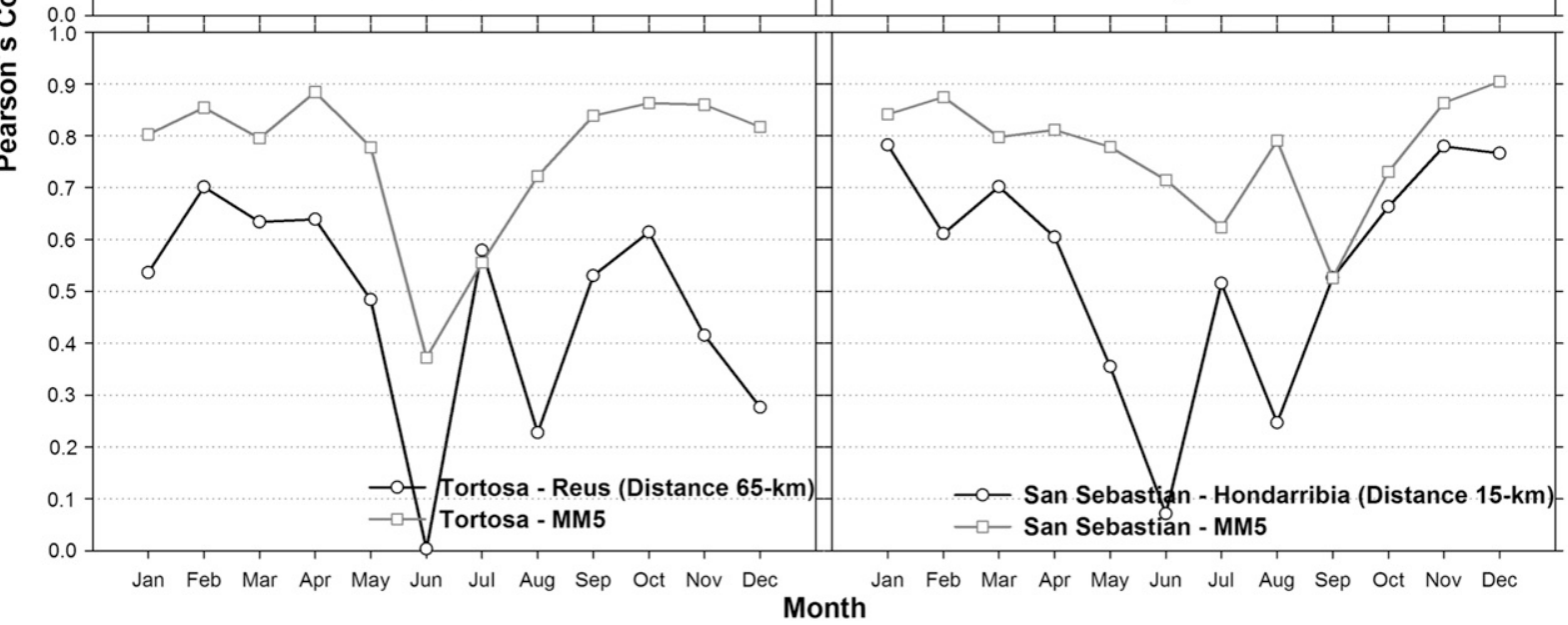

FIG. 3. Statistical relationship between observed and modeled wind speed series. (a) Average Pearson's correlation coefficients among the observed wind speed series as a function of the distance lag; (b) relative frequency histogram of the Pearson's correlation coefficients between the 76 observed wind speed series and the corresponding modeled MM5 wind speed series; and (c) monthly Pearson's correlation coefficients between the wind speed series at four locations (Lisboa, Zaragoza, Tortosa, and San Sebastian) and (i) the nearest stations placed at long, medium, and short distances (Beja, Huesca, Reus, and Hondarribia, respectively) and (ii) the MM5 series.

segment (with almost standard wind measurements at $10.5 \mathrm{~m}$ above the ground) by adding the aforementioned amount of changes to the corresponding data after the specified month. However, except for three stations, we added the amount of change before the detected break, assuming that the most recent wind speed measurements were more reliable. The importance of the homogenization of the wind speed series is confirmed by the linear 


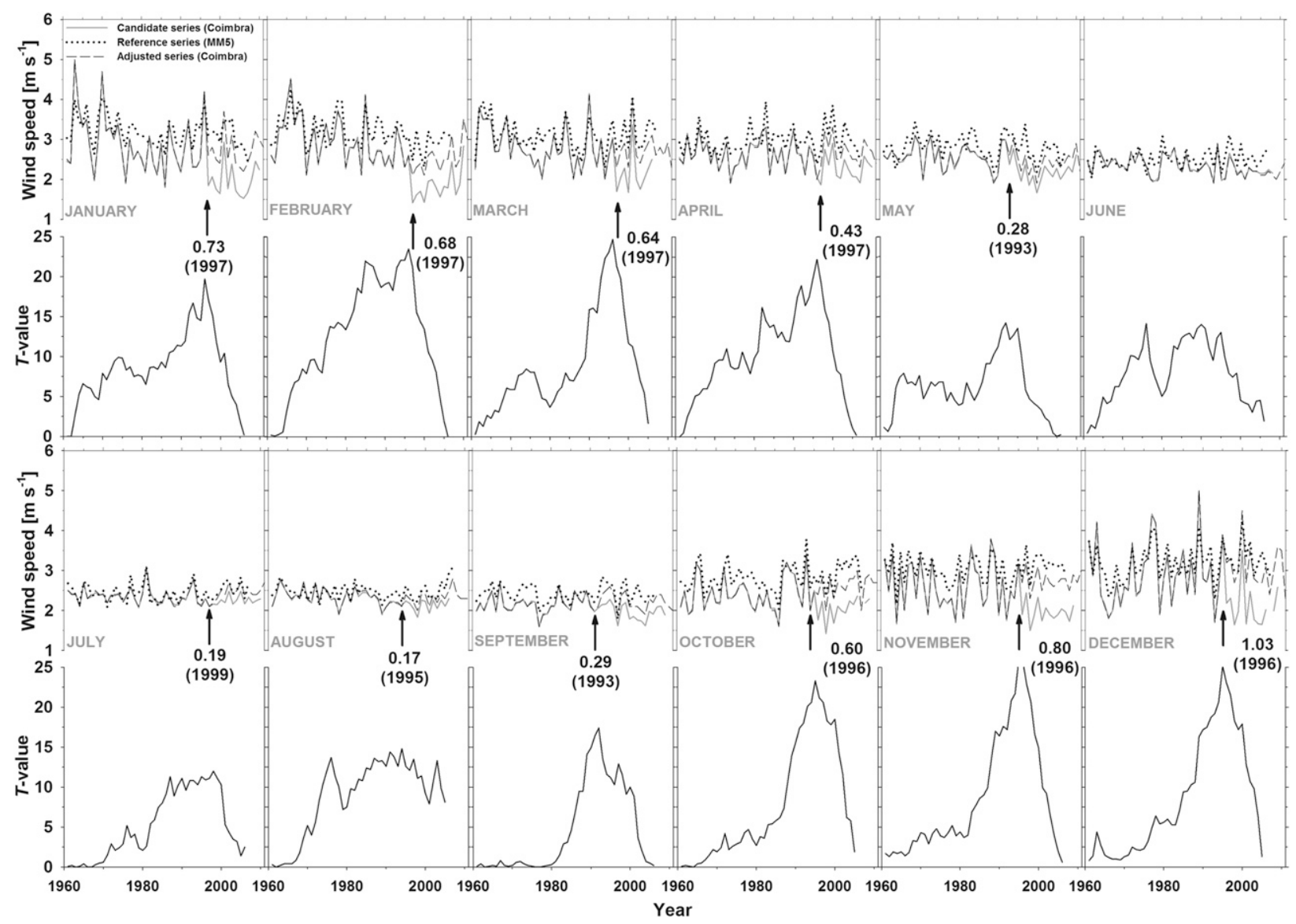

FIG. 4. Monthly original (candidate) MM5 reference and adjusted series of Coimbra station and corresponding T values of the SNHT test at monthly basis for 1961-2011. The amounts of change and years of breakpoint (in brackets) are highlighted with an arrow; for June no significant breakpoint $(p<0.05)$ was detected.

trend that diminished from $-0.140 \mathrm{~m} \mathrm{~s}^{-1}$ decade $^{-1}$ for the original series to $-0.024 \mathrm{~m} \mathrm{~s}^{-1}$ decade $^{-1}$ for the homogenized series, where the trend is measured in meter per second per decade. This example revealed the ability of simultaneously using MM5 simulations and the SNHT test to identify discontinuities in wind speed series.

To summarize (Table 1), we detected and corrected significant breaks in 472 out of 804 monthly series checked in the 76 meteorological stations (i.e., in $58.7 \%$ of the total months). After applying our data homogenization process, we also filled missing values (no more than 60 months, i.e., $5 \mathrm{yr}$ ) in the homogeneous wind speed series by using the MM5 monthly series to achieve data completeness for assessing longterm wind speed trends. Finally, records from 54 stations (46 in Spain and 8 in Portugal) and 67 stations (59 in Spain and 8 in Portugal) were used for analyzing wind speed changes and variability spanning 51 (19612011) and $30 \mathrm{yr}$ (1979-2008) (see section 4). The remaining nine stations were discarded due to the large number of inhomogeneities and missing data gaps. Thus, the final dataset consists of 67 homogenized stations located over the IP (Fig. 2b; supplementary Table S1).

\section{Trend analysis}

We first calculated single station and regional (i.e., for Spain, Portugal, and all stations) wind speed anomaly series as deviations (in $\mathrm{m} \mathrm{s}^{-1}$ ) from the 1981-2010 mean, which represents the common period for all 67 homogenized series. We expressed wind speed series as anomalies to avoid windy series dominating the regional wind speed series. We then applied a regression analysis between the series of time (independent variable) and the wind speed anomaly series (dependent variable) to calculate the sign and magnitude of the wind speed trend. The slope of the regression model represents the magnitude of the wind speed trend in meters per second per decade. Wind speed anomaly series are plotted 
TABLE 1. Summary of the homogeneity testing results.

\begin{tabular}{lccc}
\hline \hline Monthly wind speed data & All stations & Spain & Portugal \\
\hline No. of raw series & 129 & 113 & 16 \\
No. of testable series & 76 & 68 & 8 \\
$\begin{array}{l}\text { No. of significant breaks } \\
\quad \text { at } p<0.05\end{array}$ & 472 & 392 & 80 \\
$\begin{array}{l}\text { No. of homogeneous } \\
\quad \text { series 1961-2011 }\end{array}$ & 54 & 46 & 8 \\
$\begin{array}{l}\text { No. of homogeneous } \\
\quad \text { series 1979-2008 }\end{array}$ & 67 & 59 & 8 \\
\hline
\end{tabular}

together with a 15-yr Gaussian low-pass filter to illustrate long-term variability.

The statistical significance of annual, seasonal, and monthly linear trends was calculated using the nonparametric correlation coefficient of Mann-Kendall's tau-b (Kendall and Gibbons 1990), which measures the degree to which a trend is consistently increasing or decreasing. The tau-b test is more robust than parametric methods and does not assume normality of the data series (Lanzante 1996). Prior to applying the tau-b test, we accounted for the autocorrelation function of the wind speed series (von Storch 1995) since significant autocorrelations may increase the probability that the tau-b test detects a significant trend. We applied the 1-month lag autocorrelation coefficient on the series and found that there was no significant serial correlation beyond lag 0 at the $p<0.05$ significant level; therefore, we did not apply the prewhitening procedure for removing any significant autocorrelation on the wind speed series. Moreover, here we report statistically significant trends at three $p$-level thresholds, following McVicar et al. (2010), they are (i) significant at $p<0.05$, (ii) significant at $p<0.10$, and (iii) not significant at $p<$ 0.10 . Having grades of $p$ level, as opposed to a subjective binary threshold (e.g., at $p<0.05$ ), helps readers evaluate wind speed trends from a "process and importance" perspective, instead of only a "statistically significant" perspective (Weatherhead et al. 1998; Nicholls 2001). Furthermore, we applied the methods developed by Livezey and Chen (1983) and Wilks (2006) to evaluate the field significance of the detected significant trends at the $95 \%$ confidence level. This methodology serves to evaluate whether the number of stations with significant trends have occurred by chance (DadaserCelik and Cengiz 2014). Last, the Pearson's correlation coefficient at the three aforementioned $p$-level thresholds was calculated to measure the relationship between the NAOI, MOI, and WEMOI and the observed wind speed anomalies.

In the following sections we analyzed long-term variations of near-surface wind speed across the IP for climate records 51-yr long, that is, 1961-2011 (54 stations), and also for $30 \mathrm{yr}$, that is, 1979-2008 (67 stations), because (i) Vautard et al. (2010) calculated wind speed trends from 822 surface weather stations for this subperiod globally, and their results represent a reference for comparison purposes; and (ii) the sign and in particular the magnitude of the trend is sensitive to the study period considered (Troccoli et al. 2012).

\section{Results}

\section{a. Annual and seasonal wind speed trends}

Table 2a reports wind speed trends for 1961-2011 and the 30-yr subperiod; Table $2 \mathrm{~b}$ summarizes the corresponding wind speed trends exhibited by the MM5-simulated reference series for comparison. Annually, we found a negative wind speed trend of $-0.016 \mathrm{~m} \mathrm{~s}^{-1}$ decade $^{-1}$ for 1961$2011\left(-0.010 \mathrm{~m} \mathrm{~s}^{-1}\right.$ decade $^{-1}$ for 1979-2008; neither being significant at $p<0.10$ ). When analyzing wind speed trends seasonally, we found two wind speed trend patterns between the winter [December-February (DJF)] and spring [March-May (MAM)], which show declining trends, contrasting summer [June-August (JJA)] and autumn [September-November (SON)], which displayed increasing trends. For instance, a negative (but not significant at $p<0.10$ ) wind speed trend of $-0.054 \mathrm{~m} \mathrm{~s}^{-1} \mathrm{decade}^{-1}$ was found for winter, a stilling that was statistically significant at $p<0.10$ after the 1980 s, as it showed a trend of $-0.125 \mathrm{~m} \mathrm{~s}^{-1}$ decade $^{-1}$ for the $30 \mathrm{yr}$. This weak decline was also detected during the spring but with nonsignificance at the $p<0.10$ negative trend of $-0.022 \mathrm{~m} \mathrm{~s}^{-1}$ decade $^{-1}\left(-0.031 \mathrm{~m} \mathrm{~s}^{-1}\right.$ decade $^{-1}$ for 1979-2008). In contrast, the observed wind speed trends became weakly positive with $0.009 \mathrm{~m} \mathrm{~s}^{-1}$ decade $^{-1}$ $\left(0.037 \mathrm{~m} \mathrm{~s}^{-1}\right.$ decade $^{-1}$ for 1979-2008, significant at $p<$ $0.10)$ for summer and with $0.006 \mathrm{~m} \mathrm{~s}^{-1}$ decade $^{-1}$ $\left(0.053 \mathrm{~m} \mathrm{~s}^{-1}\right.$ decade $^{-1}$ for 1979-2008) for autumn. With the exception of summer for 1979-2008, all detected increases in summer-autumn wind speed are not statistically significant at $p<0.10$.

Figure 5 provides the annual and seasonal wind speed anomalies averaged over the Portuguese (8 stations) and Spanish (46 stations) series separately. We found a strong consistency between the Portuguese and Spanish stations since they are significantly $(p<0.05)$ correlated with a coefficient of 0.64 annually (Fig. 5a), 0.81 in winter (Fig. 5b), 0.71 in spring (Fig. 5c), 0.49 in summer (Fig. 5d), and 0.70 in autumn (Fig. 5e). This feature also confirmed the quality and homogeneity of the created dataset, since wind speed data were supplied by two different meteorological weather services. Overall, wind speed declined $-0.014 \mathrm{~m} \mathrm{~s}^{-1}$ decade $^{-1}\left(-0.006 \mathrm{~m} \mathrm{~s}^{-1}\right.$ decade $^{-1}$ for 1979 2008) and $-0.032 \mathrm{~m} \mathrm{~s}^{-1}$ decade $^{-1}\left(-0.038 \mathrm{~m} \mathrm{~s}^{-1}\right.$ decade $^{-1}$ 
TABLE 2. Annual and seasonal wind speed trends averaged for all stations, Spain, and Portugal for 1961-2011 (54 stations) and 19792008 (67 stations) for (a) the observed and (b) the MM5 series. Values are expressed as $\mathrm{m} \mathrm{s}^{-1} \mathrm{decade}^{-1}$. Statistically significant trends were defined as those where $p<0.10$ (in bold) and $p<0.05$ (in bold and in parenthesis).

\begin{tabular}{|c|c|c|c|c|c|c|}
\hline \multicolumn{7}{|c|}{ (a) } \\
\hline \multirow[b]{2}{*}{ Periods } & \multicolumn{2}{|c|}{ All stations } & \multicolumn{2}{|c|}{ Spain } & \multicolumn{2}{|c|}{ Portugal } \\
\hline & 1961-2011 & $1979-2008$ & 1961-2011 & $1979-2008$ & 1961-2011 & $1979-2008$ \\
\hline Annual & -0.016 & -0.010 & -0.014 & -0.006 & $(-0.032)$ & $(-0.038)$ \\
\hline Winter (DJF) & -0.054 & -0.125 & -0.047 & -0.115 & $(-0.096)$ & $(-0.193)$ \\
\hline Spring (MAM) & -0.022 & -0.031 & -0.018 & -0.028 & $(-0.044)$ & -0.058 \\
\hline Summer (JJA) & 0.009 & $\mathbf{0 . 0 3 7}$ & 0.010 & 0.041 & 0.000 & 0.008 \\
\hline Autumn (SON) & 0.006 & 0.053 & 0.003 & 0.052 & 0.021 & 0.061 \\
\hline \multicolumn{7}{|c|}{ (b) } \\
\hline & \multicolumn{2}{|c|}{ All stations } & \multicolumn{2}{|c|}{ Spain } & \multicolumn{2}{|c|}{ Portugal } \\
\hline Periods & 1961-2011 & $1979-2008$ & 1961-2011 & $1979-2008$ & 1961-2011 & 1979-2008 \\
\hline Annual & -0.004 & 0.003 & -0.002 & 0.003 & -0.015 & 0.005 \\
\hline Winter (DJF) & -0.054 & -0.088 & -0.053 & -0.089 & -0.059 & -0.079 \\
\hline Spring (MAM) & -0.007 & -0.037 & -0.004 & -0.034 & -0.025 & -0.058 \\
\hline Summer (JJA) & 0.025 & 0.050 & 0.027 & $(0.050)$ & 0.015 & (0.049) \\
\hline Autumn (SON) & 0.024 & 0.076 & 0.025 & 0.073 & 0.016 & (0.094) \\
\hline
\end{tabular}

for 1979-2008) for Spain and Portugal, respectively. Stilling was $\sim 3$ times higher in Portugal, which was also statistically significant at $p<0.05$ for both periods (Fig. 5a; Table 2). Furthermore, the 15-yr Gaussian low-pass filter reveals that wind speed gradually decreased until the 2000s; during the 1990s the rate of decline was more pronounced, whereas the wind speed rebounded to predominantly positive increases (albeit small) during last decade (i.e., 2000-10). Moreover, we also encountered the abovementioned seasonal differences in the sign of wind speed change for both countries. For instance, the strongest and most significant declining was found in winter, in particular for Portugal (Fig. 5b), being of less magnitude and statistical significance in spring (Fig. 5c). In contrast, fairly positive wind speed trends of less statistical significance were observed in summer (Fig. 5d) and in autumn (Fig. 5e).

\section{b. Spatial distribution of wind speed trends}

Figure 6 shows the spatial distribution of the sign, magnitude of change, and statistical significance of wind speed trends for 1961-2011 (54 stations); these are summarized in Table 3. Overall, wind speed trends do not display a clear spatial distribution and, therefore, heterogeneity is a characteristic feature since positive and negative trends can appear over short distances. Annually (Fig. 6a), wind declined at $63.0 \%$ of stations, with $38.2 \%$ and $44.1 \%$ of these stations showing stilling statistically significant at $p<0.05$ and $p<0.10$, respectively. Seasonally, it is clearly evident that wind stilling dominated winter and spring. For instance, the declining wind speed occurred in $77.8 \%$ of the stations in winter (Fig. 6b), with $31.0 \%$ and $38.1 \%$ of these negative trends being statistically significant at the $p<0.05$ and $p<0.10$ levels, respectively. For spring (Fig. 6c), stilling was present in $66.7 \%$ of the stations, with $27.8 \%$ and $38.9 \%$ of these being statistically significant at $p<0.05$ and $p<0.10$, respectively. In contrast, the declining tendency was smaller during summer (Fig. 6d) and autumn (Fig. 6e), with only $48.1 \%$ and $42.6 \%$ of stations, respectively, exhibiting stilling. For these two seasons, the sign dominance corresponded to weakly positive wind speed trends, with $51.9 \%$ (summer, with $46.4 \%$ being statistically significant at both $p<0.05$ and $p<$ 0.10 ) and $57.4 \%$ (autumn, with $16.1 \%$ and $25.8 \%$ being statistically significant at $p<0.05$ and $p<0.10$, respectively) of the stations reporting increasing trends. The results of applying the methods of Livezey and Chen (1983) and Wilks (2006) showed field significance higher than the $95 \%$ level for annual and seasonal time scales in all significant (at $p<0.05$ and $p<0.10$ ) trends reported in Table 3.

Figure 7 shows wind speed trends for the 30-yr 19792008 subperiod (67 stations) being characterized by a stronger magnitude of changes; the summary is provided in Table 3. However, the percentage of stations displaying wind stilling was a bit lower with $55.2 \%$ of stations at the annual time scale (Fig. 7a), but the statistical significance of this stilling was greater with $43.2 \%$ and $54.1 \%$ of the declining stations being significant at $p<0.05$ and $p<0.10$, respectively. Seasonally, stilling was more widespread and statistically significant occurring in $82.1 \%$ of stations in winter (Fig. $7 b$ ). For spring, $62.7 \%$ of stations had declining trends 


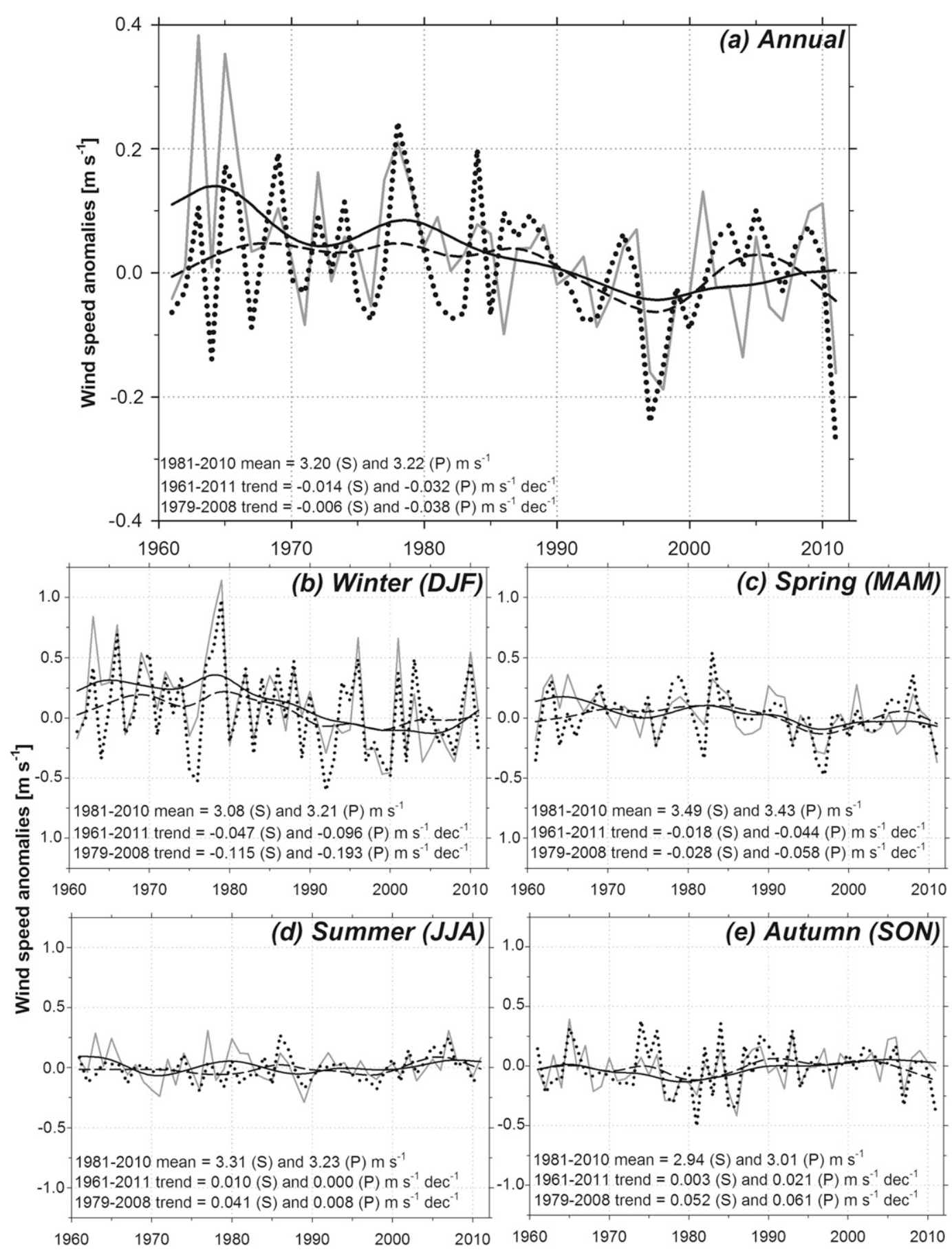

FIG. 5. Mean annual and seasonal wind speed anomalies $\left(\mathrm{m} \mathrm{s}^{-1}\right)$ series for Spain (S; black dotted line) and Portugal (P; dark gray solid line) from 1961 to 2011. The 15-yr Gaussian low-pass filter is also shown with a black dashed line for Spain and with a black solid line for Portugal. The series are expressed as anomalies from the 1981-2010 mean.

(Fig. 7c). For 1979-2008, the stilling decreased to $41.8 \%$ of stations in summer (Fig. 7d), with the percentages being slightly lower in autumn (Fig. 7e) in $37.3 \%$ of stations. Therefore, increases in near-surface wind speed dominated in these two latter seasons with $58.2 \%$ of stations in summer and $62.7 \%$ of stations in autumn. For the 30-yr 1979-2008 subperiod, all reported statistically significant (at $p<0.05$ and $p<0.10$ ) trends in Table 3 and also showed field significance higher than the $95 \%$ level. 


\section{Wind speed trends 1961-2011}

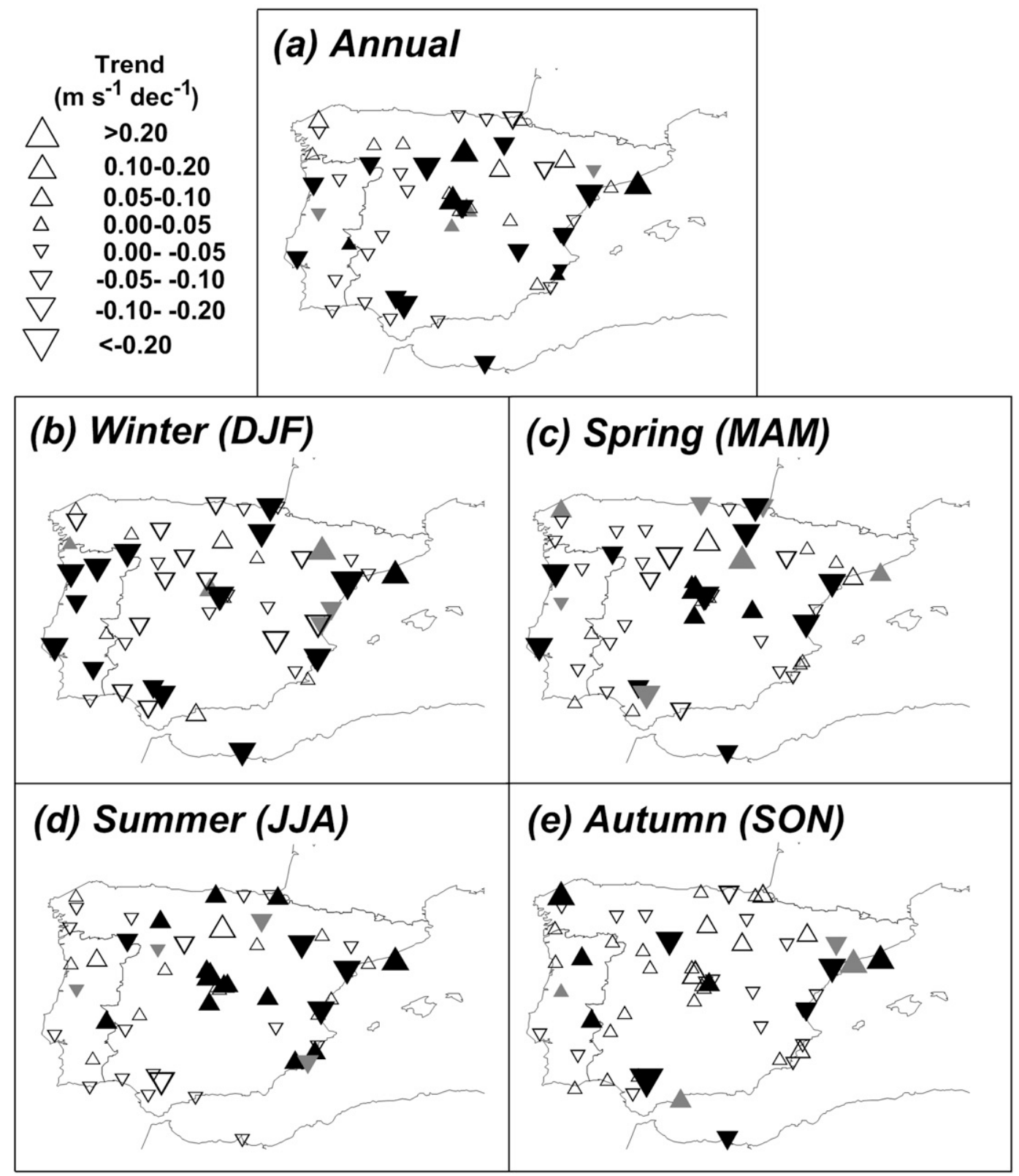

Non-filled $=$ not significant at the $p<0.10$ level

Dark grey filled $=$ significant at the $p<0.10$ level

Black filled $=$ significant at the $p<0.05$ level

FIG. 6. Spatial distribution of the sign, magnitude of trend (in $\mathrm{m} \mathrm{s}^{-1} \mathrm{decade}^{-1}$ ), and statistical significance (black filled triangles are significant at $p<0.05$; dark gray filled triangles are significant at $p<0.10$; and nonfilled triangles are not significant at $p<0.10$ ) of wind speed trends for 54 stations for 1961-2011.

\section{Possible causes of observed wind speed trends}

a. Influence of large-scale atmospheric circulation

We evaluated the impact of the large-scale circulation modes on the wind speed variability by analyzing the
NAOI, MOI, and WEMOI. Figure 8 and Table 4 show that the NAOI exerted its major influence in winter, with negative significant $p<0.05$ correlations of -0.55 (1961-2011) and -0.57 (1979-2008; supplementary Fig. S2) for all series affecting the majority of the IP, 
TABLE 3. Relative frequency of stations showing significant (at $p<0.05$ and $p<0.10$ ) and nonsignificant (at $p>0.10)$ negative and positive wind speed trends annually and seasonally for 1961-2011 (54 stations) and 1979-2008 (67 stations). For the three $p$-level thresholds, relative frequencies are calculated with respect to the total number of stations showing negative or positive tendencies.

\begin{tabular}{|c|c|c|c|c|c|c|c|c|}
\hline \multicolumn{9}{|c|}{$1961-2011$} \\
\hline Periods & Negative & $\begin{array}{l}\text { Negative } \\
p<0.05\end{array}$ & $\begin{array}{l}\text { Negative } \\
p<0.10\end{array}$ & $\begin{array}{l}\text { Negative } \\
p>0.10\end{array}$ & Positive & $\begin{array}{l}\text { Positive } \\
p<0.05\end{array}$ & $\begin{array}{l}\text { Positive } \\
p<0.10\end{array}$ & $\begin{array}{l}\text { Positive } \\
p>0.10\end{array}$ \\
\hline Annual & 63.0 & 38.2 & 44.1 & 55.9 & 37.0 & 25.0 & 35.0 & 65.0 \\
\hline Winter (DJF) & 77.8 & 31.0 & 38.1 & 61.9 & 22.2 & 8.3 & 33.3 & 66.7 \\
\hline Spring (MAM) & 66.7 & 27.8 & 38.9 & 61.1 & 33.3 & 22.2 & 38.9 & 61.1 \\
\hline Summer (JJA) & 48.1 & 15.4 & 30.8 & 69.2 & 51.9 & 46.4 & 46.4 & 53.6 \\
\hline Autumn (SON) & 42.6 & 21.7 & 26.1 & 73.9 & 57.4 & 16.1 & 25.8 & 74.2 \\
\hline \multicolumn{9}{|c|}{ 1979-2008 } \\
\hline Annual & 55.2 & 43.2 & 54.1 & 45.9 & 44.8 & 33.3 & 40.0 & 60.0 \\
\hline Winter (DJF) & 82.1 & 32.7 & 45.5 & 54.5 & 17.9 & 25.0 & 33.3 & 66.7 \\
\hline Spring (MAM) & 62.7 & 26.2 & 35.7 & 64.3 & 37.3 & 32.0 & 36.0 & 64.0 \\
\hline Summer (JJA) & 41.8 & 17.9 & 39.3 & 60.7 & 58.2 & 33.3 & 46.2 & 53.8 \\
\hline Autumn (SON) & 37.3 & 12.0 & 16.0 & 84.0 & 62.7 & 33.3 & 40.5 & 59.5 \\
\hline
\end{tabular}

especially Portugal. Moreover, the positive, but not significant $(p<0.10)$, decadal trend of the winter NAOI for 1961-2011 and 1979-2008 (Table 5) might explain the observed winter stilling, having been more pronounced in the last $30 \mathrm{yr}$ in the western IP. In contrast, we found that the spring NAOI exerted a negligible influence with $r$ of -0.14 (1961-2011) and -0.01 (19792008), yet exhibited a clear spatial pattern of negative and significant (mostly at $p<0.05$ ) correlations in the southern IP and positive but not significant $(p<0.10)$ relationships in the northern IP for 1961-2011 and more widespread positive but not significant $(p<0.10)$ correlations for 1979-2008. The spring stilling, weaker than the winter one, might be explained by other atmospheric circulation patterns as shown below. For summer, the NAOI exerted a moderate and significant $(p<0.05)$ impact with $r$ of -0.33 (1961-2011) and -0.51 (1979$2008)$ and showed a negative and significant $(p<0.05)$ decadal trend for 1961-2011 and 1979-2008. This might explain the wind speed increase observed in summer during the last three decades, particularly in Spain. Similarly, we also detected a significant $(p<0.05)$ impact of the NAOI in autumn, with $r$ of -0.36 (19612011) and -0.34 (1979-2008), accompanied by a negative and significant $(p<0.05)$ decadal trend for 19612011 and 1979-2008. This could partly explains the weak but significant $(p<0.10)$ (for Portugal) tendency of increasing autumn wind speed detected over the last three decades. Use of the summer-NAOI (SNAOI) (Bladé et al. 2012) did not reveal major changes when compared to the use of NAOI (see Table 6).

The winter MOI showed a negative and significant $(p<0.05)$ relationship with correlations of -0.48 (19612011) and -0.43 (1979-2008), exerting its major influence across the entire study area except the northern fringe of the IP. As occurred for the NAOI, we also found a positive but not significant $(p<0.10)$ decadal trend of the winter MOI for 1961-2011 and 1979-2008; that is, the positive phases are becoming more frequent and are also leading the observed winter stilling. Negative and significant $(p<0.05)$ correlations were also encountered in autumn with -0.35 (1961-2011) and -0.56 (1979-2008), which among a negative and significant decadal trend for 1961-2011 $(p<0.05)$ and 1979-2008 $(p<0.10)$ might explain the observed weak autumn wind increasing, particularly over Portugal during last three decades. In contrast, the impact of the MOI on the wind speed trends appears to be weaker during spring and summer (see Fig. 8 and supplementary Fig. S2).

Last, the most regional teleconnection index, the WEMOI, exerted its major influence in spring (when the NAOI exhibited its weakest impact), with positive significant $(p<0.05)$ correlations of $0.48(1961-2011)$ and 0.54 (1979-2008); this is the opposite sign when compared to the NAOI and MOI influences. Additionally, negative and significant $(p<0.05)$ decadal trends of the spring WEMOI for 1961-2011 and 1979-2008 were observed, which means a weakening of the positive phases could be partly causing the observed weak spring stilling. With a lesser importance, the winter WEMOI is also positively and significantly correlated with the winter wind speed, being $r$ of $0.32(p<0.05 ; 1961-2011)$ and $0.31(p<0.10 ; 1979-2008)$, with the exception of the southwest IP (where the NAOI exhibited its strongest influence) under the domain of the Azores high during positive phases. Negative and significant $(p<0.05)$ decadal trends of the winter WEMOI for 1961-2011, and particularly 1979-2008, might also have influenced the detected winter stilling. For summer and autumn, 


\section{Wind speed trends 1979-2008}

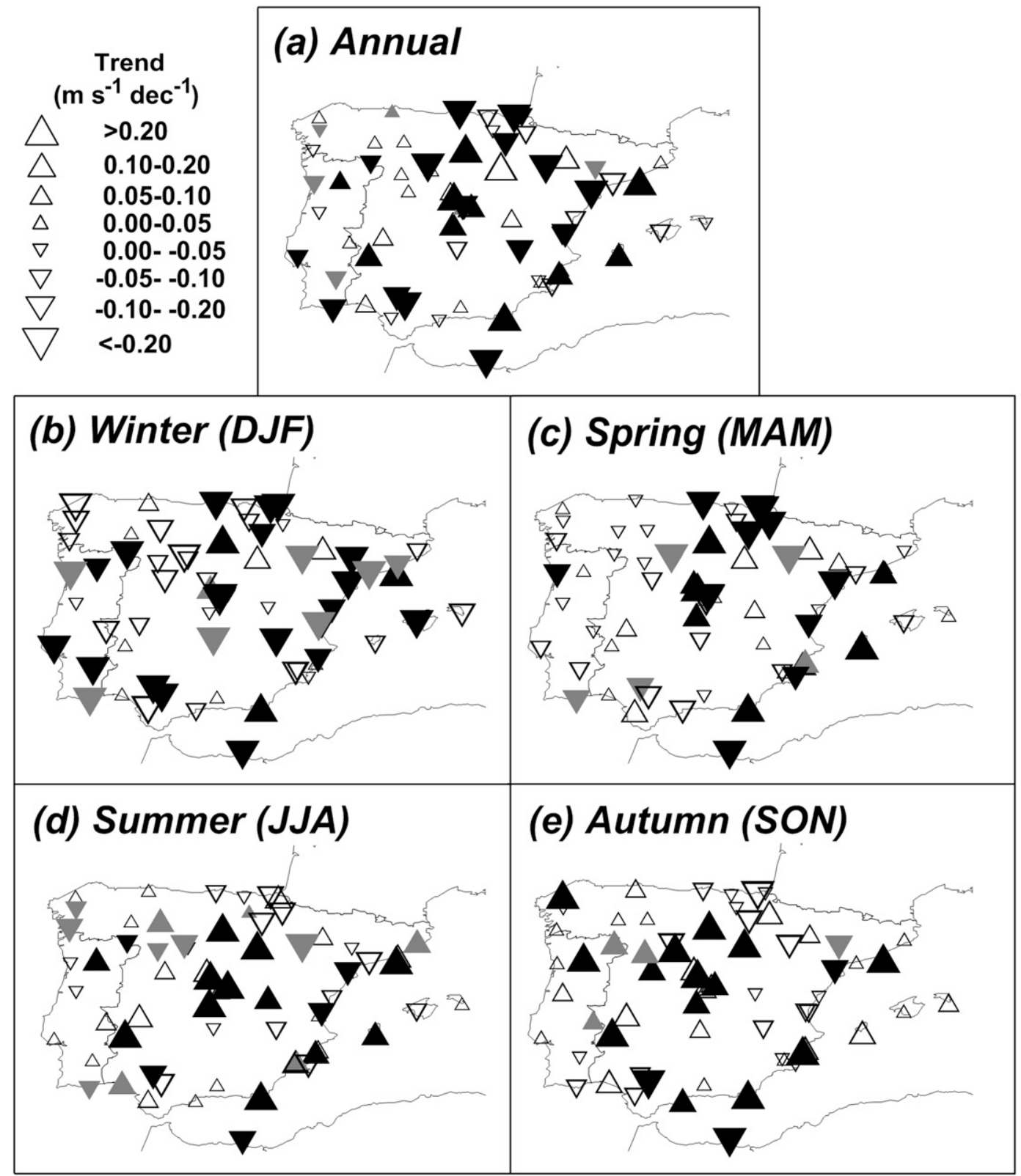

Non-filled $=$ not significant at the $p<0.10$ level

Dark grey filled $=$ significant at the $p<0.10$ level

Black filled $=$ significant at the $p<0.05$ level

FIG. 7. As in Fig. 6, but for 67 stations for 1979-2008.

the WEMOI does not display a significant $(p<0.10)$ influence.

\section{b. Influence of urban roughness}

Table 7 shows differences in annual and seasonal wind speed trends for three locations (Madrid, Valencia, and
Alicante) where accurate data were simultaneously measured at proximally located airports (i.e., wellexposed sites with few artificial obstacles and negligibly affected by urbanization and changes in land use) and at city centers (i.e., poor-exposed sites with high buildings, street canyons, and forested city parks), which lead to 
1961-2011

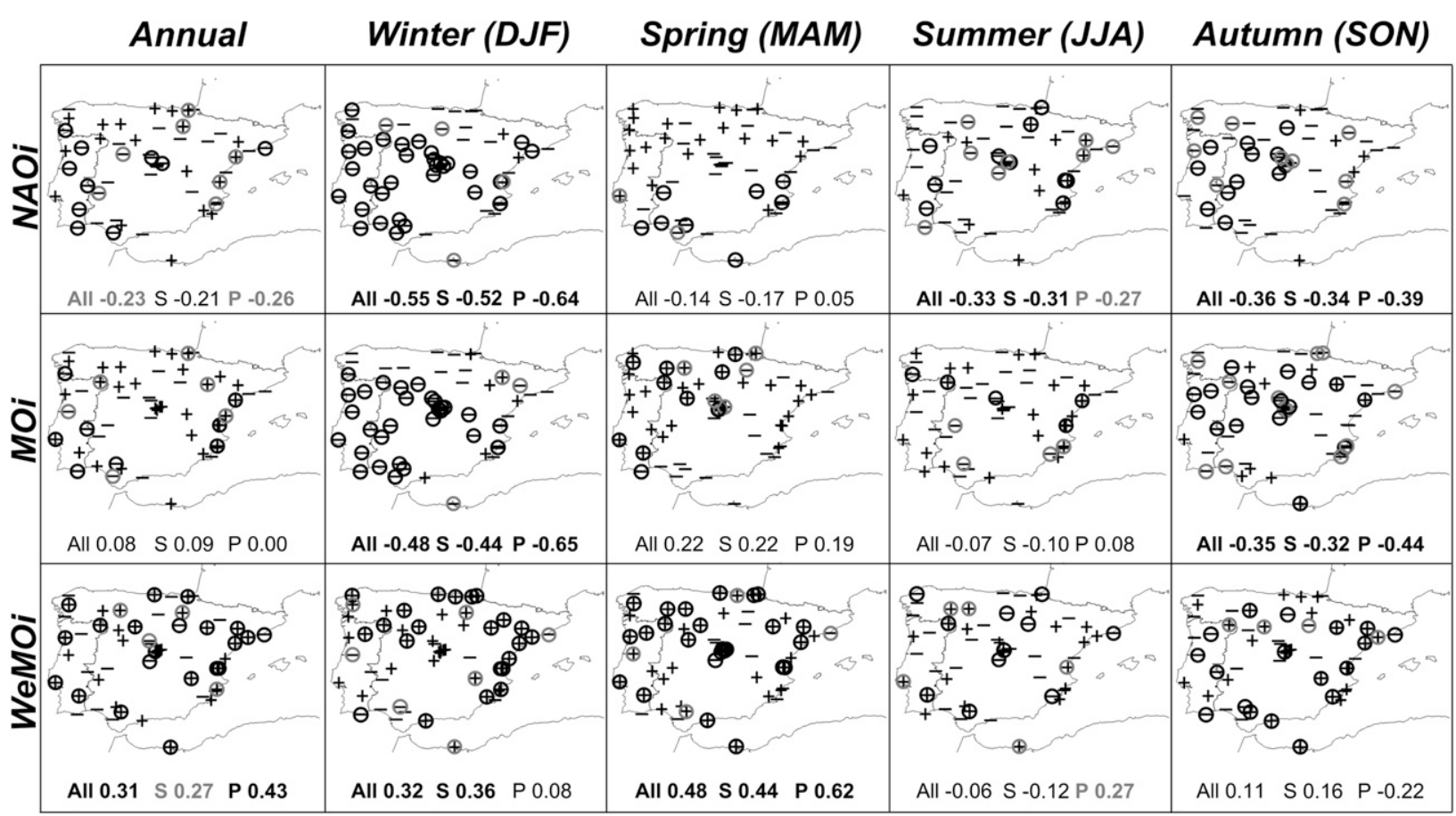

$\bigoplus$ Positive correlation and significant at the $p<0.05$ level $\bigoplus$ Positive correlation and significant at the $p<0.10$ level $\quad+$ Positive correlation but not significant at the $p<0.10$ level

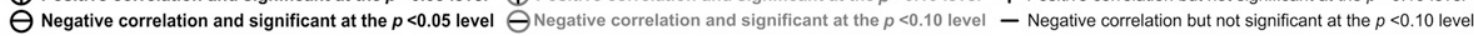

FIG. 8. Annual and seasonal spatial distributions of the sign and significance of Pearson's correlation relationship between wind speed anomalies (in m s${ }^{-1}$ ) and the NAOI, MOI, and WEMOI for 1961-2011. Below each figure are shown Pearson's correlation coefficients for (i) all stations (All), (ii) Spain (S), and (iii) Portugal (P), with $p<0.05$ (black bold type), at $p<0.10$ (dark gray bold type), and not significant at $p<0.10$ (black unbold type).

strong environment changes. This analysis was restricted to only these three locations as they are the only station pairs proximally located (i.e., $<15 \mathrm{~km}$ ) having accurate data simultaneously observed under both conditions.
For Madrid, the capital and biggest city of Spain (third largest metropolitan area in Europe covering $604.3 \mathrm{~km}^{2}$ inhabited by 6.5 million people), we found a different sign and magnitude of change in the wind

TABLE 4. Number of stations showing negative and positive and significant (at $p<0.05$ ) Pearson's correlation coefficients between wind speed anomalies (in $\mathrm{m} \mathrm{s}^{-1}$ ) and the NAOI, MOI, and WEMOI annually and seasonally for 1961-2011 (54 stations) and 1979-2008 (67 stations).

\begin{tabular}{|c|c|c|c|c|c|c|c|c|c|c|c|c|}
\hline \multicolumn{13}{|c|}{ 1961-2011 } \\
\hline \multirow[b]{2}{*}{ Periods } & \multicolumn{4}{|c|}{ NAOI } & \multicolumn{4}{|c|}{ MOI } & \multicolumn{4}{|c|}{ WEMOI } \\
\hline & $(-)$ & $(-)<0.05$ & $(+)$ & $(+)<0.05$ & $(-)$ & $(-)<0.05$ & $(+)$ & $(+)<0.05$ & $(-)$ & $(-)<0.05$ & $(+)$ & $(+)<0.05$ \\
\hline Annual & 25 & 10 & 19 & 0 & 19 & 4 & 27 & 4 & 17 & 3 & 16 & 18 \\
\hline Winter (DJF) & 19 & 33 & 2 & 0 & 18 & 30 & 6 & 0 & 11 & 1 & 21 & 21 \\
\hline Spring (MAM) & 25 & 8 & 21 & 0 & 16 & 1 & 28 & 9 & 11 & 1 & 17 & 25 \\
\hline Summer (JJA) & 30 & 10 & 12 & 2 & 29 & 2 & 20 & 3 & 24 & 7 & 19 & 4 \\
\hline Autumn (SON) & 37 & 12 & 5 & 0 & 30 & 14 & 7 & 3 & 16 & 7 & 20 & 11 \\
\hline \multicolumn{13}{|c|}{ 1979-2008 } \\
\hline Annual & 35 & 3 & 28 & 1 & 26 & 1 & 39 & 1 & 20 & 9 & 31 & 7 \\
\hline Winter (DJF) & 27 & 36 & 4 & 0 & 39 & 23 & 5 & 0 & 11 & 2 & 36 & 18 \\
\hline Spring (MAM) & 30 & 1 & 34 & 2 & 24 & 1 & 37 & 5 & 12 & 0 & 29 & 26 \\
\hline Summer (JJA) & 44 & 10 & 13 & 0 & 34 & 2 & 31 & 0 & 31 & 7 & 26 & 3 \\
\hline Autumn (SON) & 43 & 9 & 15 & 0 & 39 & 19 & 9 & 0 & 23 & 9 & 26 & 9 \\
\hline
\end{tabular}


TABLE 5. Annual and seasonal trends of NAOI, MOI, and WEMOI for 1961-2011 and for 1979-2008. Values are expressed as standardized sea level pressure difference. Statistically significant trends were defined as those where $p<0.10$ (in bold) and $p<0.05$ (in bold and in parenthesis).

\begin{tabular}{|c|c|c|c|c|c|c|}
\hline \multirow[b]{2}{*}{ Periods } & \multicolumn{2}{|c|}{ NAOI } & \multicolumn{2}{|c|}{ MOI } & \multicolumn{2}{|c|}{ WEMOI } \\
\hline & 1961-2011 & 1979-2008 & 1961-2011 & 1979-2008 & 1961-2011 & 1979-2008 \\
\hline Annual & -0.082 & $(-0.200)$ & $(-0.083)$ & 0.001 & $(-0.165)$ & $(-0.230)$ \\
\hline Winter (DJF) & 0.080 & 0.113 & 0.062 & 0.112 & $(-0.146)$ & $(-0.322)$ \\
\hline Spring (MAM) & -0.025 & -0.018 & -0.006 & 0.189 & $(-0.276)$ & $(-0.328)$ \\
\hline Summer (JJA) & $(-0.241)$ & $(-0.463)$ & $(-0.216)$ & -0.048 & -0.116 & -0.089 \\
\hline Autumn (SON) & $(-0.172)$ & $(-0.353)$ & $(-0.162)$ & -0.220 & $(-0.148)$ & -0.189 \\
\hline
\end{tabular}

speed trends between the Madrid-Barajas airport $\left(0.051 \mathrm{~m} \mathrm{~s}^{-1}\right.$ decade $\left.^{-1}\right)$ and Madrid-Retiro park in the city center $\left(-0.071 \mathrm{~m} \mathrm{~s}^{-1}\right.$ decade $\left.^{-1}\right)$ annually over $1961-$ 2011; that is, the wind speed decreased $0.122 \mathrm{~m} \mathrm{~s}^{-1}$ decade $^{-1}$ more in Madrid city than in the surrounding area. This opposite pattern of increasing wind speed trends at the Madrid-Barajas airport and declining wind speed trends at the Madrid-Retiro park also occurred seasonally: winter $\left(0.172 \mathrm{~m} \mathrm{~s}^{-1}\right.$ decade $\left.^{-1}\right)$, spring $\left(0.154 \mathrm{~m} \mathrm{~s}^{-1}\right.$ decade $\left.^{-1}\right)$, and autumn $\left(0.091 \mathrm{~m} \mathrm{~s}^{-1}\right.$ decade $\left.^{-1}\right)$, summer being the only exception when wind speed increases in both sites but less at Madrid-Retiro $\left(0.059 \mathrm{~m} \mathrm{~s}^{-1}\right.$ decade $\left.^{-1}\right)$. Other well-exposed rural or suburban stations surrounding Madrid city (e.g., Madrid-Cuatro Vientos, Torrejón de Ardoz, and Puerto de Navacerrada; not shown) also displayed similar wind speed trends as MadridBarajas airport, confirming a potential impact of urbanization on the important stilling observed in the Madrid-Retiro station. Trend differences between rural and urban areas in Madrid are similar for the 1979-2008 subperiod.

For Valencia (third largest metropolitan area in Spain covering $628.9 \mathrm{~km}^{2}$ and inhabited by 1.7 million people), annually we also encountered a stronger stilling in the Valencia-Viveros park in the city center $\left(-0.099 \mathrm{~m} \mathrm{~s}^{-1}\right.$ decade $\left.^{-1}\right)$, when compared to ValenciaManises airport $\left(-0.036 \mathrm{~m} \mathrm{~s}^{-1} \mathrm{decade}^{-1}\right)$ for 1961-2011. That is, the wind speed decreased $0.063 \mathrm{~m} \mathrm{~s}^{-1}$ decade $^{-1}$ more in Valencia city than the surrounding area. This also occurred in spring $\left(0.110 \mathrm{~m} \mathrm{~s}^{-1}\right.$ decade $\left.^{-1}\right)$, summer $\left(0.130 \mathrm{~m} \mathrm{~s}^{-1} \mathrm{decade}^{-1}\right)$, and autumn $\left(0.049 \mathrm{~m} \mathrm{~s}^{-1}\right.$ decade $\left.^{-1}\right)$. Winter was an exception when the wind speed declined $0.030 \mathrm{~m} \mathrm{~s}^{-1}$ decade $^{-1}$ more in the Valencia-Manises airport than in the Valencia city. For the 1979-2008 subperiod, these trend differences mostly increased, in particular and negatively in winter when wind speed decreased $0.254 \mathrm{~m} \mathrm{~s}^{-1}$ decade $^{-1}$ more in the ValenciaManises airport.

Last, for Alicante (the eighth largest metropolitan area in Spain covering $474.2 \mathrm{~km}^{2}$ and inhabited by 0.5 million people), we also observed the impact of urban roughness on wind speed trends. Annually for 19612011, the wind speed trend increased at the unobstructed Alicante-El Altet airport $\left(0.024 \mathrm{~m} \mathrm{~s}^{-1}\right.$ decade $\left.^{-1}\right)$, whereas it declined in the Alicante-C. Jardin station located in the city $\left(-0.044 \mathrm{~m} \mathrm{~s}^{-1}\right.$ decade $\left.^{-1}\right)$; that is, the wind speed decreased $0.068 \mathrm{~m} \mathrm{~s}^{-1}$ decade $^{-1}$ more in the Alicante city than in the surrounding area. This also occurred for all seasons: winter $\left(0.142 \mathrm{~m} \mathrm{~s}^{-1}\right.$ decade $\left.^{-1}\right)$, spring $\left(0.013 \mathrm{~m} \mathrm{~s}^{-1}\right.$ decade $\left.^{-1}\right)$, summer $\left(0.062 \mathrm{~m} \mathrm{~s}^{-1} \mathrm{decade}^{-1}\right)$, and autumn $\left(0.063 \mathrm{~m} \mathrm{~s}^{-1} \mathrm{decade}^{-1}\right)$. For the 1979-2008 subperiod, even though increasing trends in wind speed dominated, the positive differences between the airport area and the city center also increased, confirming the role of urbanization growth occurred over last $50 \mathrm{yr}$ on the declining of wind speed in urban areas.

\section{Summary and discussion}

We used anemometer observations from 67 landbased sites across the Iberian Peninsula and the Balearic Islands to assess long-term trends of wind speed for 1961-2011, with particular attention to the 1979-2008 subperiod. We proposed a novel approach for homogenizing wind speed data using simulated series obtained with the MM5. These modeled wind speed series were

TABLE 6. Number of stations showing negative and positive and significant (at $p<0.05$ ) Pearson's correlation coefficients between wind speed anomalies (in $\mathrm{m} \mathrm{s}^{-1}$ ) and the NAOI and SNAOI during summer for 1961-2011 (54 stations).

\begin{tabular}{|c|c|c|c|c|c|c|c|c|}
\hline \multirow[b]{2}{*}{ Periods } & \multicolumn{4}{|c|}{ NAOI } & \multicolumn{4}{|c|}{ SNAOI } \\
\hline & $(-)$ & $(-)<0.05$ & $(+)$ & $(+)<0.05$ & $(-)$ & $(-)<0.05$ & $(+)$ & $(+)<0.05$ \\
\hline Summer (JJA) & 30 & 10 & 12 & 2 & 31 & 6 & 17 & 0 \\
\hline
\end{tabular}


TABLE 7. Annual and seasonal wind speed trends (in $\mathrm{m} \mathrm{s}^{-1}$ decade $^{-1}$ ) for three selected rural and urban stations for 1961-2011 and 1979-2008. The R and U acronyms correspond to rural and urban stations, respectively. Statistically significant trends were defined as those where $p<0.10$ (in bold) and $p<0.05$ (in bold and in parenthesis).

\begin{tabular}{|c|c|c|c|c|c|c|c|c|c|}
\hline \multicolumn{10}{|c|}{ 1961-2011 } \\
\hline \multirow[b]{2}{*}{ Periods } & \multicolumn{3}{|c|}{ Madrid } & \multicolumn{3}{|c|}{ Valencia } & \multicolumn{3}{|c|}{ Alicante } \\
\hline & Barajas (R) & Retiro (U) & $(\mathrm{R}-\mathrm{U})$ & Manises (R) & Viveros (U) & $(\mathrm{R}-\mathrm{U})$ & Altet (R) & C. Jardin (U) & $(\mathrm{R}-\mathrm{U})$ \\
\hline Annual & 0.051 & -0.071 & 0.122 & -0.036 & $(-0.099)$ & 0.063 & $(0.024)$ & $(-0.044)$ & 0.068 \\
\hline Winter (DJF) & 0.046 & $(-0.126)$ & 0.172 & -0.108 & -0.078 & -0.030 & -0.042 & $(-0.184)$ & 0.142 \\
\hline Spring (MAM) & 0.017 & $(-0.137)$ & 0.154 & -0.015 & $(-0.125)$ & 0.110 & 0.023 & 0.010 & 0.013 \\
\hline Summer (JJA) & (0.088) & 0.029 & 0.059 & 0.024 & $(-0.106)$ & 0.130 & $(0.058)$ & -0.004 & 0.062 \\
\hline Autumn (SON) & $(0.054)$ & -0.037 & 0.091 & $\begin{array}{l}-0.042 \\
\quad 1979-200\end{array}$ & $8^{(-\mathbf{0 . 0 9 1})}$ & 0.049 & 0.060 & -0.003 & 0.063 \\
\hline Annual & -0.019 & $(-0.146)$ & 0.127 & -0.081 & $(-0.115)$ & 0.034 & $(0.157)$ & 0.038 & 0.119 \\
\hline Winter (DJF) & -0.030 & $(-0.218)$ & 0.188 & -0.368 & -0.114 & -0.254 & 0.020 & $(-0.171)$ & 0.191 \\
\hline Spring (MAM) & -0.169 & $(-0.304)$ & 0.135 & -0.012 & $(-0.147)$ & 0.135 & $(0.156)$ & 0.145 & 0.011 \\
\hline Summer (JJA) & 0.009 & -0.049 & 0.058 & 0.043 & $(-0.110)$ & 0.153 & (0.190) & 0.090 & 0.100 \\
\hline Autumn (SON) & 0.078 & -0.030 & 0.108 & -0.062 & -0.090 & 0.028 & $(0.241)$ & 0.100 & 0.141 \\
\hline
\end{tabular}

used as reference series because a preliminary statistical evaluation showed a good agreement with the observed wind speed series, improving the poorer performance achieved by considering nearby stations (Wang 2008). The homogenization procedure suggested here represents a robust and alternative technique to the previous few attempts on this issue, mainly based on (i) basic quality controls (Pirazzoli and Tomasin 2003), standard checks (McVicar et al. 2010), and more sophisticated examinations (Jiménez et al. 2010; Troccoli et al. 2012) and (ii) objective statistical homogeneity tests based on geostrophic wind (Wan et al. 2010) or data from nearby stations ( $\mathrm{Li}$ et al. 2011) as reference series. Therefore, we encourage future long-term wind speed studies to establish a robust homogenization protocol applying a combination of both (i) and (ii) procedures outlined above. Also use of simulated data, instead of geostrophic winds or nearby stations, as reference series was warranted in this area of complex topography where wind is driven by thermal and pressure gradients and friction forces (Barry and Chorley 2003). Even though our relative homogeneity test does not depend on metadata, we also suggest future research to recover it, as much as possible (e.g., relocation of stations and anemometer height changes), to improve the assessment of breakpoints ( $\mathrm{Li}$ et al. 2011).

Our study assesses for the first time long-term wind speed trends across the entire IP, revealing new evidence regarding the atmospheric stilling in a region located within the transition between the subtropical high-pressure belt and the midlatitude westerlies. Overall, annual wind speed trends showed a slow decline for both study periods. Seasonally there was a dominance of declining trends in winter and spring and a tendency of increasing trends in summer and autumn. The magnitude of the trends was sensitive to the length of the study period, which is in agreement with McVicar et al. (2010) and Troccoli et al. (2012); the trends were stronger for the shorter 30-yr subperiod. Wind stilling affected much of the stations in winter and less in spring, but was statistically significant at $p<0.10$ in roughly $40 \%$ of the stations in both seasons. In summer and autumn, increasing trends affected slightly over half the stations, with also around $40 \%$ of the positive trends being statistically significant at the $p<0.10$ level.

To our knowledge, these seasonal wind speed trend patterns (i.e., negative winter and spring trend and positive summer and autumn trend) have not been previously reported. Although increases and decreases of wind speed trends have been reported within the vicinity of the Mediterranean Sea (see McVicar et al. 2012a, their Table 2 and Fig. 2). Comparisons with previous wind speed trend results across IP (Recio et al. 2009; Jiménez et al. 2010; Espadafor et al. 2011; Moratiel et al. 2011) are difficult to establish because they used fewer stations (i.e., focused on specific regions) and different observation lengths (generally shorter), which can impact results (McVicar et al. 2010; Troccoli et al. 2012). However, our results are in close agreement with previous assessments of Mediterranean terrestrial stilling $\left(-0.010 \mathrm{~m} \mathrm{~s}^{-1}\right)$ obtained by Papaioannou et al. (2011) over Greece for 1959-2001 and by Pirazzoli and Tomasin (2003), who concluded that wind trends were nonmonotonic over the central Mediterranean region for 1951-2000. Nevertheless, for 1979-2008, the overall weak declining trend reported here is $\sim 9$ times weaker $\left(-0.010 \mathrm{~m} \mathrm{~s}^{-1}\right.$ decade $\left.^{-1}\right)$ than that reported by Vautard et al. (2010) across Europe $\left(-0.090 \mathrm{~m} \mathrm{~s}^{-1}\right.$ decade $\left.^{-1}\right)$. The annual atmospheric stilling has been smaller over the southern midlatitudes in Europe, which are primarily 
controlled by weak winds under the subtropical highpressure belt, whereas surface wind speeds have markedly declined in northern midlatitudes in Europe (i.e., primarily controlled by strong winds under the influence of storms tracks associated with the polar jet stream) (Smits et al. 2005). This process could be attributed to the faster slowing of strong winds than weak winds over this northern region as found by Vautard et al. 2010. Furthermore, the weak but not significant $p<0.10$ fall in winds found in our study agrees with the terrestrial stilling reported by McVicar et al. (2012a), who reported an average trend of $-0.140 \mathrm{~m} \mathrm{~s}^{-1}$ decade $^{-1}$ for studies with more than 30 stations and spanning more than $30 \mathrm{yr}$.

The precise cause of the stilling remains largely uncertain (Vautard et al. 2010; McVicar et al. 2012a) and few studies have investigated the contribution from changes in the large-scale atmospheric circulation (Bichet et al. 2012); we attributed much of the trends reported for the IP to be probably associated with decadal variability of some atmospheric circulation indices. We found that the NAOI is responsible for much of the wind speed declining in winter, which is strongly supported by the observed decadal increase in the winter NAOI (Osborn 2011). For instance, Winkler (2010) and Earl et al. (2013) linked the anomalously low wind 2009-10 year in Germany and the United Kingdom, respectively, to the extremely negative values of NAOI in winter since records began in 1821. In Switzerland, Beniston (2005) also pointed out that wind speed trends are likely driven by the NAOI. The strong influence of the NAOI on the interannual variations of the wind speed over the IP has been also reported by Jerez et al. (2013b). Additionally, Osborn (2011) used the Coupled Model Intercomparison Project phase 3 (CMIP3) ensemble of 21 climate models and showed that increasing anthropogenic forcings (e.g., greenhouse gases) might force a shift of atmospheric circulation toward positive NAOI phases. This would hypothetically lead to a weakening of wind speed over the midlatitude Mediterranean regions much controlled by the northward shifting of the subtropical high-pressure belt (Gillett and Stott 2009). Consequently, the poleward expansion of the Hadley cell and consequent change in the pressure gradients (i.e., in response to global warming) and the observed increasing altitude of the tropopause (Santer et al. 2003) could also partly be explaining the slowdown in large-scale atmospheric circulation (Lu et al. 2007). Additionally, we also found a possible influence of the NAOI on the increased wind speed observed during summer and autumn, which is supported by the negative decadal tendency detected for the summer-autumn NAOI. Other atmospheric circulation patterns, the
MOI and WEMOI, also exhibited a possible influence on the observed wind speed variability during the last 5 decades for the IP. Furthermore, we also illustrated with three major Spanish cities how the urbanization growth (Li et al. 2011) might have strengthened the observed atmospheric stilling. However, we suggest that the local influence of urbanization might explain a relatively small fraction of the observed wind speed trends in comparison to the large-scale atmospheric circulation, since most of the stations used in this study are located in rural or suburban environments (e.g., mainly airports). This agrees with (i) Li et al. (2011)'s report that urbanization was responsible for $20 \%$ of declines in the Beijing area in 1960-2008 and (ii) Guo et al. (2011), who reported similar "urban" and "rural" trends for two study periods using an all China 652-station database.

Other potential causes of declining wind speed such as (i) an upward trend in land surface roughness due to an increase in vegetative biomass (e.g., enhanced carbon dioxide concentrations have caused increasing amounts of vegetation; Donohue et al. 2013), land use changes, and urbanization (Vautard et al. 2010); (ii) instrumental drifts and technological improvements, maintenance, and shifts in measurements sites and calibration issues (DeGaetano 1998; Wan et al. 2010); (iii) sunlight dimming due to air pollution (Xu et al. 2006; Jacobson and Kaufman 2006); and (iv) astronomical changes (Mazzarella 2007), and so on, should be further investigated for unraveling the causes of the ongoing stilling over land globally. On the other hand, the reported increasing trends in summer and autumn may respond to local phenomenon such as a soil moisture depletion (Cerdà 2002) reinforcing the Iberian thermal low (Jerez et al. 2012). Acknowledging that several processes on local, regional, and global scales are likely contributing (McVicar and Roderick 2010), further investigation is needed to attribute the decadal variability of large-scale atmospheric circulation as the main cause of the observed wind speed trends across the IP.

Acknowledgments. The authors wish to acknowledge the editor and three anonymous reviewers for their detailed and helpful comments to the original manuscript. This research was supported by (i) the JAE-DOC043 (CSIC; European Social Fund, FSE) and the JCI-201110263 Grants; (ii) A. S.-L. received a postdoctoral fellowship from the Secretaria per a Universitats i Recerca del Departament d'Economia i Coneixement, de la Generalitat de Catalunya i del programa Cofund de les Accions Marie Curie del 7è Programa marc d' $R+D$ de la Unió Europea (2011 BP-B 00078); (iii) Projects CGL201127574-C02-02, CGL2011-27536/HID, CGL2011-29263C02-01, and PSE.120000.2007.14, financed by the Spanish 
Commission of Science and Technology and FEDER; ACQWA (FP7-ENV- 2008-1-212250), financed by the European Comission; Efecto de los escenarios de cambio climático sobre la hidrología superficial y la gestión de embalses del Pirineo Aragonés, financed by Obra Social La Caixa; CTTP1/12 Creación de un modelo de alta resolución espacial para cuantificar la esquiabilidad y la afluencia turística en el Pirineo bajo distintos escenarios de cambio climático, financed by the Comunidad de Trabajo de los Pirineos; ENAC (PTDC/AAC-CLI/ 103567/2008), financed by the Portuguese Science Foundation; and (iv) the Climatology Group (2009 SGR 443, Catalan Government). The authors thank the AEMET and the IPMA institutions for the observed wind data and particularly José-Antonio Guijarro (AEMET-Baleares) and Juan-José Vizcaíno (AEMET-Valencia) for their useful comments and information. We thank Ptr Stepanek for providing the AnClim software and the MAR research group of the University of Murcia for providing the MM5-simulated wind speed series, particularly the assistance of Raquel Lorente-Plazas and Juan Pedro Montávez.

\section{REFERENCES}

Aguilar, E., I. Auer, M. Brunet, T. C. Peterson, and J. Wieringa, 2003: Guidelines on climate metadata and homogenization. World Meteorological Organization Tech Rep. WMO/TD 1186, 52 pp. [Available online at http://www.wmo.int/datastat/ documents/WCDMP-53_1.pdf.]

Alexandersson, H., 1986: A homogeneity test to precipitation data. Int. J. Climatol., 6, 661-675, doi:10.1002/joc.3370060607.

Azorin-Molina, C., and J. Martin-Vide, 2007: Methodological approach to the study of the daily persistence of the sea breeze in Alicante (Spain). Atmósfera, 20, 57-81.

- D. Chen, S. Tijm, and M. Baldi, 2011: A multi-year study of sea breezes in a Mediterranean coastal site: Alicante (Spain). Int. J. Climatol., 31, 468-486, doi:10.1002/joc.2064.

Barry, R. G., and R. J. Chorley, 2003: Atmosphere, Weather and Climate. Routledge, $421 \mathrm{pp}$.

Beniston, M., 2005: Mountain climates and climatic change: An overview of processes focusing on the European Alps. Pure Appl. Geophys., 162, 1587-1606, doi:10.1007/s00024-005-2684-9.

Bernstein, L., and Coauthors, 2007: Climate Change 2007: Synthesis Report. IPCC, 104 pp.

Bichet, A., M. Wild, D. Folini, and C. Schär, 2012: Causes for decadal variations of wind speed over land: Sensitivity studies with a global climate model. Geophys. Res. Lett., 39, L11701, doi:10.1029/2012GL051685.

Bladé, I., B. Liebmann, D. Fortuny, and G. J. van Oldenborgh, 2012: Observed and simulated impacts of the summer NAO in Europe: Implications for projected drying in the Mediterranean region. Climate Dyn., 39, 709-727, doi:10.1007/ s00382-011-1195-x.

Brázdil, R., K. Chromá, P. Dobrovolný, and R. Tolasz, 2009: Climate fluctuations in the Czech Republic during the period 1961-2005. Int. J. Climatol., 29, 223-242, doi:10.1002/ joc. 1718 .
Cardone, V. J., and J. G. Greenwood, 1990: On trends in historical marine wind data. J. Climate, 3,113-127, doi:10.1175/ 1520-0442(1990)003<0113:OTIHMW > 2.0.CO;2.

Cerdà, A., 2002: The effect of season and parent material on water erosion on highly eroded soils in eastern Spain. J. Arid Environ., 52, 319-337, doi:10.1006/jare.2002.1009.

Coelingh, J. P., A. J. M. van Wijk, and A. A. M. Holtslag, 1996: Analysis of wind speed observations over the North Sea. J. Wind Eng. Ind. Aerodyn., 61, 51-69, doi:10.1016/ 0167-6105(96)00043-8.

Dadaser-Celik, F., and E. Cengiz, 2014: Wind speed trends over Turkey from 1975 to 2006. Int. J. Climatol., doi:10.1002/ joc.3810, in press.

DeGaetano, A. T., 1998: Identification and implications of biases in U.S. surface wind observation, archival, and summarization methods. Theor. Appl. Climatol., 60, 151-162, doi:10.1007/ s007040050040.

Donohue, R. J., M. L. Roderick, T. R. McVicar, and G. D. Farquhar, 2013: Impact of $\mathrm{CO}_{2}$ fertilization on maximum foliage cover across the globe's warm, arid environments. Geophys. Res. Lett., 40, 3031-3035, doi:10.1002/ grl.50563.

Earl, N., S. Dorling, R. Hewston, and R. von Glasow, 2013: 19802010 variability in U.K. surface wind climate. J. Climate, 26, 1172-1191, doi:10.1175/JCLI-D-12-00026.1.

El Kenawy, A., J. I. López-Moreno, P. Stepanek, and S. M. VicenteSerrrano, 2013: An assessment of the role of homogenization protocol in the performance of daily temperature series and trends: Application to northeastern Spain. Int. J. Climatol., 33, 87-108, doi:10.1002/joc.3410.

Espadafor, M., I. J. Lorite, P. Gavilán, and J. Berengena, 2011: An analysis of the tendency of reference evapotranspiration estimates and other climate variables during the last 45 years in southern Spain. Agric. Water Manage., 98, 1045-1061, doi:10.1016/ j.agwat.2011.01.015.

Evans, J. P., R. B. Smith, and R. J. Oglesby, 2004: Middle East climate simulation and dominant precipitation processes. Int. J. Climatol., 24, 1671-1694, doi:10.1002/joc.1084.

Gillett, N. P., and P. A. Stott, 2009: Attribution of anthropogenic influence on seasonal sea level pressure. Geophys. Res. Lett., 36, L23709, doi:10.1029/2009GL041269.

Gokturk, O. M., D. Bozkurt, O. L. Sen, and M. Karaca, 2008: Quality control and homogeneity of Turkish precipitation data. Hydrol. Processes, 22, 3210-3218, doi:10.1002/hyp.6915.

Grell, G. A., J. Dudhia, and D. R. Stauffer, 1994: A description of the fifth-generation Penn State/NCAR Mesoscale Model (MM5). NCAR Tech. Note NCAR/TN-398+STR, 128 pp. [Available online at http://nldr.library.ucar.edu/repository/ assets/technotes/TECH-NOTE-000-000-000-214.pdf.]

Guo, H., M. Xu, and Q. Hu, 2011: Changes in near-surface wind speed in China: 1969-2005. Int. J. Climatol., 31, 349-358, doi:10.1002/joc.2091.

Hoinka, K. P., and M. de Castro, 2003: The Iberian thermal low. Quart. J. Roy. Meteor. Soc., 129, 1491-1511, doi:10.1256/ qj.01.189.

Hughes, M., A. Hall, and R. G. Fovell, 2009: Blocking in areas of complex topography and its influence on rainfall distribution. J. Atmos. Sci., 66, 508-518, doi:10.1175/2008JAS2689.1.

Jacobson, M. Z., and Y. J. Kaufman, 2006: Wind reduction by aerosol particles. Geophys. Res. Lett., 33, L24814, doi:10.1029/ 2006GL027838.

Jerez, S., J. P. Montavez, J. J. Gomez-Navarro, P. Jimenez-Guerrero, J. Jimenez, and J. F. Gonzalez-Rouco, 2010: Temperature 
sensitivity to the land-surface model in MM5 climate simulations over the Iberian Peninsula. Meteor. Z., 19, 363-374, doi:10.1127/0941-2948/2010/0473.

,,,--- P. A. Jiménez, P. Jimenez-Guerrero, R. LorentePlazas, and J. F. Gonzalez-Rouco, 2012: The role of the landsurface model for climate change projections over the Iberian Peninsula. J. Geophys. Res., 117, D01109, doi:10.1029/ 2011JD016576.

- — - P. Jimenez-Guerrero, J. J. Gomez-Navarro, R. LorentePlazas, and E. Zorita, 2013a: A multi-physics ensemble of present-day climate regional simulations over the Iberian Peninsula. Climate Dyn., 40, 3023-3046, doi:10.1007/ s00382-012-1539-1.

—, R. M. Trigo, S. M. Vicente-Serrano, D. Pozo-Vázquez, R. Lorente-Plazas, J. Lorenzo-Lacruz, F. Santos-Alamillos, and J. P. Montávez, 2013b: The impact of the North Atlantic Oscillation on the renewable energy resources in southwestern Europe. J. Appl. Meteor. Climatol., 52, 2204-2225, doi:10.1175/ JAMC-D-12-0257.1.

Jiménez, P. A., O. Jorba, R. Parra, and J. M. Baldasano, 2006: Evaluation of MM5-EMICAT2000-CMAQ performance and sensitivity in complex terrain: High-resolution application to the northeastern Iberian Peninsula. Atmos. Environ., 40, 5056-5072, doi:10.1016/j.atmosenv.2005.12.060.

— , J. F. González-Rouco, J. Navarro, J. P. Montávez, and E. García-Bustamante, 2010: Quality assurance of surface wind observations from automated weather stations. J. At mos. Oceanic Technol., 27, 1101-1122, doi:10.1175/ 2010JTECHA1404.1.

Jones, P. D., T. Jonsson, and D. Wheeler, 1997: Extension to the North Atlantic Oscillation using early instrumental pressure observations from Gibraltar and south-west Iceland. Int. J. Climatol., 17, 1433-1450, doi:10.1002/(SICI)1097-0088 (19971115)17:13<1433::AID-JOC203>3.0.CO;2-P.

Kanamitsu, M., W. Ebisuzaki, J. Woollen, S.-K. Yang, J. J. Hnilo, M. Fiorino, and G. L. Potter, 2002: NCEP-DOE AMIP-II Reanalysis (R-2). Bull. Amer. Meteor. Soc., 83, 1631-1643, doi:10.1175/BAMS-83-11-1631.

Kendall, M. G., and J. D. Gibbons, 1990: Rank Correlation Methods. Oxford University Press, $272 \mathrm{pp}$.

Klink, K., 1999: Trends in mean monthly maximum and minimum surface wind speeds in the coterminous United States, 1961 to 1990. Climate Res., 13, 193-205, doi:10.3354/ cr013193.

Lanzante, J. R., 1996: Resistant, robust and non-parametric techniques for the analysis of climate data: Theory and examples, including applications to historical radiosonde station data. Int. J. Climatol., 16, 1197-1226, doi:10.1002/(SICI)1097-0088(199611)16: $11<1197:: A I D-J O C 89>3.0 . C O ; 2-\mathrm{L}$

Li, Z., Z. Yan, K. Tu, W. Liu, and Y. Wang, 2011: Changes in wind speed and extremes in Beijing during 1960-2008 based on homogenized observations. Adv. Atmos. Sci., 28, 408-420, doi:10.1007/s00376-010-0018-Z

Livezey, R. E., and W. Y. Chen, 1983: Statistical field significance and its determination by Monte Carlo techniques. Mon. Wea. Rev., 111, 46-59, doi:10.1175/1520-0493(1983)111<0046 SFSAID $>2.0 . \mathrm{CO} ; 2$.

Lorente-Plazas, R., and Coauthors, 2012: EOLMAP: A web tool to assess the wind resource over Spain. Proc. Int. Conf. on Renewable Energies and Power Quality (ICREPQ '12), Santiago de Compostela, Spain, European Association for the Development of Renewable Energies, Environment and Power
Quality (EA4EPQ), 95-105. [Available online at http://www. icrepq.com/icrepq \%2712/673-lorente.pdf.]

Lu, J., G. A. Vecchi, and T. Reichler, 2007: Expansion of the Hadley cell under global warming. Geophys. Res. Lett., 34, L06805, doi:10.1029/2006GL028443.

Martin-Vide, J., and J. A. Lopez-Bustins, 2006: The western Mediterranean oscillation and rainfall in the Iberian Peninsula. Int. J. Climatol., 26, 1455-1475, doi:10.1002/joc.1388.

Mazzarella, A., 2007: The 60-year solar modulation of global air temperature: The earth's rotation and atmospheric circulation connection. Theor. Appl. Climatol., 88, 193-199, doi:10.1007/ s00704-005-0219-z.

McVicar, T. R., and M. L. Roderick, 2010: Atmospheric science: Winds of change. Nat. Geosci., 3, 747-748, doi:10.1038/ ngeo1002.

- and C. Körner, 2013: On the use of elevation, altitude and height in the ecological and climatology literature. Oecologia, 171, 335-337, doi:10.1007/s00442-012-2416-7.

T. G. Van Niel, L. T. Li, M. L. Roderick, D. P. Rayner, L. Ricciardulli, and R. J. Donohue, 2008: Wind speed climatology and trends for Australia, 1975-2006: Capturing the stilling phenomenon and comparison with near-surface reanalysis output. Geophys. Res. Lett., 35, L20403, doi:10.1029/ 2008GL035627.

, M. L. Roderick, L. T. Li, X. G. Mo, N. E. Zimmermann, and D. R. Schmatz, 2010: Observational evidence from two mountainous regions that near-surface wind speeds are declining more rapidly at higher elevations than lower elevations: 1960-2006. Geophys. Res. Lett., 37, L06402, doi:10.1029/ 2009GL042255.

, and Coauthors, 2012a: Global review and synthesis of trends in observed terrestrial near-surface wind speeds: Implications for evaporation. J. Hydrol., 416-417, 182-205, doi:10.1016/ j.jhydrol.2011.10.024.

, M. L. Roderick, R. J. Donohue, and T. G. Van Niel, 2012b: Less bluster ahead? Ecohydrological implications of global trends of terrestrial near-surface wind speeds. Ecohydrology, 5, 381-388, doi:10.1002/eco.1298.

Moratiel, R., R. L. Snyder, J. M. Durán, and A. M. Tarquis, 2011: Trends in climatic variables trends and future reference evapotranspiration in Duero Valley (Spain). Nat. Hazards Earth Syst. Sci., 11, 1795-1805, doi:10.5194/nhess-11-1795-2011.

Nicholls, N., 2001: The insignificance of significance testing. Bull. Amer. Meteor. Soc., 82, 981-986, doi:10.1175/1520-0477(2001)082<0981: CAATIO $>2.3 . \mathrm{CO} ; 2$

Osborn, T. J., 2011: Variability and changes in the North Atlantic Oscillation index. Hydrological, Socioeconomic and Ecological Impacts of the North Atlantic Oscillation in the Mediterranean Region, S. M. Vicente-Serrano and R. M. Trigo, Eds., Advances in Global Change Research Series, Vol. 46, Springer, 9-22.

Otero, C., C. Manchado, R. Arias, V. M. Bruschi, V. GómezJáuregui, and A. Cendrero, 2012: Wind energy development in Cantabria, Spain. Methodological approach, environmental, technological and social issues. Renewable Energy, 40, 137149, doi:10.1016/j.renene.2011.09.008.

Palutikof, J. P., 2003: Analysis of Mediterranean climate data: Measured and modelled. Mediterranean Climate: Variability and Trends, H. J. Bolle, Ed., Springer-Verlag, 125-132.

Papaioannou, G., G. Kitsara, and S. Athanasatos, 2011: Impact of global dimming and brightening on reference evapotranspiration in Greece. J. Geophys. Res., 116, D09107, doi:10.1029/ 2010JD015525. 
Petrović, P., M. Curley, M. Éireann, and I. Tošić, 2008: Detect inhomogeneities in wind direction and speed data from Iceland. Proc. Meeting of COST-ES0601 (HOME) Action Management Committee and Working Groups and the Sixth Seminar for Homogenization and Quality Control in Climatological Databases, Budapest, Hungary, Hungarian Meteorological Service, 28 pp. [Available online at http://www.homogenisation.org/ v_02_15/.]

Pinard, J.-P., 2007: Wind climate of the Whitehorse area. Arctic, 60, 227-237, doi:10.14430/arctic215.

Pirazzoli, P. A., and A. Tomasin, 2003: Recent near-surface wind changes in the central Mediterranean and Adriatic areas. Int. J. Climatol., 23, 963-973, doi:10.1002/joc.925.

Pryor, S. C., and Coauthors, 2009: Wind speed trends over the contiguous United States. J. Geophys. Res., 114, D14105, doi:10.1029/2008JD011416.

Rahimzadeh, F., A. Mohammad Noorian, M. Pedram, and M. C. Kruk, 2011: Wind speed variability over Iran and its impact on wind power potential: A case study for Esfehan Province. Meteor. Appl., 18, 198-210, doi:10.1002/met.229.

Recio, M., F. J. Rodríguez-Rajo, M. V. Jato, M. M. Trigo, and B. Cabezudo, 2009: The effect of recent climatic trends on Urticaceae pollination in two bioclimatically different areas in the Iberian Peninsula: Malaga and Vigo. Climatic Change, 97, 215-228, doi:10.1007/s10584-009-9620-4.

Roderick, M. L., L. D. Rotstayn, G. D. Farquhar, and M. T. Hobbins, 2007: On the attribution of changing pan evaporation. Geophys. Res. Lett., 34, L17403, doi:10.1029/ 2007GL031166.

Santer, B. D., and Coauthors, 2003: Contributions of anthropogenic and natural forcing to recent tropopause height changes. Science, 301, 479-483, doi:10.1126/science.1084123.

Smits, A., A. M. G. Klein-Tank, and G. P. Können, 2005: Trends in storminess over the Netherlands, 1962-2002. Int. J. Climatol., 25, 1331-1344, doi:10.1002/joc.1195.

Stepanek, P., 2004: AnClim: Software for time series analysis and homogenization. Department of Geography, Faculty of Natural Sciences, Masaryk University, 1.47 MB. [Available online at http://www.climahom.eu/software-solution/anclim.]

Trenberth, K. E., and D. A. Paolino Jr., 1980: The Northern Hemisphere sea-level pressure data set: Trends, errors and discontinuities. Mon. Wea. Rev., 108, 855-872, doi:10.1175/ 1520-0493(1980)108<0855:TNHSLP $>2.0$.CO;2.

Troccoli, A., K. Muller, P. Coppin, R. Davy, C. Russell, and A. L. Hirsch, 2012: Long-term wind speed trends over Australia. J. Climate, 25, 170-183, doi:10.1175/2011JCLI4198.1.

Uppala, S. M., and Coauthors, 2005: The ERA-40 Re-Analysis. Quart. J. Roy. Meteor. Soc., 131, 2961-3012, doi:10.1256/ qj.04.176.

Vautard, R., J. Cattiaux, P. Yiou, J.-N. Thépaut, and P. Ciais, 2010: Northern Hemisphere atmospheric stilling partly attributed to an increase in surface roughness. Nat. Geosci., 3, 756-761, doi:10.1038/ngeo979.
Venema, V. K. C., and Coauthors, 2012: Benchmarking homogenization algorithms for monthly data. Climate Past, 8, 89-115, doi:10.5194/cp-8-89-2012.

Vicente-Serrano, S. M., and R. M. Trigo, 2011: Hydrological, Socioeconomic and Ecological Impacts of the North Atlantic Oscillation in the Mediterranean Region. Advances in Global Change Research Series, Vol. 46, Springer, 236 pp.

von Storch, H., 1995: Misuses of statistical analysis in climate research. Analysis of Climate Variability: Applications of Statistical Techniques, H. von Storch and A. Navarra, Eds., Springer, 11-26.

Vose, R. S., R. L. Schmoyer, P. M. Steurer, T. C. Peterson, R. Heim, T. R. Karl, and J. Eischeid, 1992: The global historical climatology network: Long-term monthly temperature, precipitation, sea level pressure, and station pressure data. Carbon Dioxide Information Analysis Center Tech Rep. ORNL/CDIAC-53 NDP-041, 324 pp. [Available online at http://cdiac.ornl.gov/ftp/ndp041/ndp041.pdf.]

Wan, H., L. W. Xiaolan, and V. R. Swail, 2010: Homogenization and trend analysis of Canadian near-surface wind speeds. J. Climate, 23, 1209-1225, doi:10.1175/2009JCLI3200.1.

Wang, X. L., 2008: Accounting for autocorrelation in detecting mean shifts in climate data series using the penalized maximal $t$ or $F$ test. J. Appl. Meteor. Climatol., 47, 2423-2444, doi:10.1175/2008JAMC1741.1.

Weatherhead, E. C., and Coauthors, 1998: Factors affecting the detection of trends: Statistical considerations and applications to environmental data. J. Geophys. Res., 103, 17149-17161, doi:10.1029/98JD00995.

Wentz, F. J., L. Ricciardulli, K. Hilburn, and C. Mears, 2007: How much more rain will global warming bring? Science, 317, 233-235, doi:10.1126/science.1140746.

Wever, N., 2012: Quantifying trends in surface roughness and the effect on surface wind speed observations. J. Geophys. Res., 117, D11104, doi:10.1029/2011JD017118.

Wilks, D. S., 2006: On "field significance" and the false discovery rate. J. Appl. Meteor. Climatol., 45, 1181-1189, doi:10.1175/ JAM2404.1.

Winkler, W., 2010: Long-term wind speed trends in Germany. Proc. 10th German Wind Energy Conf., Bremen, Germany, DEWI, 1-4. [Available online at http://www.gl-garradhassan. com/assets/downloads/Long_Term_Wind_Speed_Trends_in_ Germany.pdf.]

WMO, 2008: Guide to meteorological instruments and methods of observation. 7th ed. World Meteorological Organization Tech. Rep. 8, 681 pp. [Available online at http://www.wmo.int/ pages/prog/gcos/documents/gruanmanuals/CIMO/CIMO_Guide7th_Edition-2008.pdf.]

Xu, M., C. P. Chang, C. Fu, Y. Qi, A. Robock, D. Robinson, and H. Zhang, 2006: Steady decline of East Asian monsoon winds, 1969-2000: Evidence from direct ground measurements of wind speed. J. Geophys. Res., 111, D24111, doi:10.1029/ 2006JD007337. 